\title{
NOMINAL AND VERBAL NUMBER IN BILUGU OPO*
}

\author{
Joshua A. G. Smolders \\ SIL International
}

\begin{abstract}
Opo (a.k.a. Opuuo, T'apo [lgn]), a Koman language spoken in Ethiopia and South Sudan, has complex and interesting systems of both NOMINAL NUMBER and VERBAL NUMBER. This paper provides a description and analysis of these systems as found in the Bilugu dialect of Ethiopia, using Corbett's (2000) model of number systems as a theoretical framework. In Bilugu Opo, NOMINAL NUMBER marking is divided along the animacy hierarchy into two systems. The TOP SYSTEM, encompassing all human referents, marks singular $\sim$ plural opposition via a variety of morphological strategies (lexical, derivational, and inflectional) and patterns (marked plural, marked singular, and both marked). The SECOND SYSTEM, encompassing all non-human referents, encodes GENERAL NUMBER. In the Opo verb system, VERBAL NUMBER (Corbett 2000) or PLURACTIONALITY (Newman 1990) is attested for just under half of verbs. These verbs can be organized into two groups: a large group which derive a plural stem through morpho-phonemic means (tone modification, vowel gemination, and reduplication) with unpredictable semantics, and a small group which derive a plural stem through lexical means (suppletion and stem alternation) with more predictable semantics.
\end{abstract}

Keywords: Nilo-Saharan, Koman, Opo, T'apo, Opuuo, number, general number, transnumeral, associative number, participant nominalization, verbal number, pluractional, pluractionality, event number, participant number, animacy hierarchy.

\section{Introduction}

This paper describes both NOMINAL NUMBER and VERBAL NUMBER in Opo (a.k.a. Opuuo, T'apo, ISO 639-3 [lgn]), a Koman language of Ethiopia and South Sudan, with a particular focus on the Bilugu dialect of Ethiopia. ${ }^{1}$ Number in Opo is interesting because of both its morphological and semantic diversity. With regard to NOMINAL NUMBER there are two systems: the TOP SYSTEM which encodes a basic singular plural opposition, and the SECOND SYSTEM which encodes GENERAL NUMBER (\$2). Within the TOP SYSTEM all three possible patterns of number marking for a singular $\sim$ plural opposition are attested (i.e. marked plural, marked singular, and marked singular and plural

\footnotetext{
* Data for this paper was collected in partnership with the Canada Institute of Linguistics at Trinity Western University (Langley, Canada) and Addis Ababa University (Addis Ababa, Ethiopia). The project was also supported in part by SIL Ethiopia and the Gambella Ministry of Culture and Tourism. A previous analysis of some of the material in $\S 3$ was presented during the 13th Nilo-Saharan Linguistics Colloquium in Addis Ababa, April 2017, and also for a special linguistics colloquium at Trinity Western University in Langley, October 2017. Special thanks is owed to Justin Goldberg of SIL International and Manuel Otero of the University of Oregon for their participation in some of the research sessions, and to my other colleagues in Koman linguistics for their valuable input. Special thanks to the Opo of Wanke and Longkwe for their hospitality during my visits.

${ }^{1}$ Throughout this paper I use SMALL CAPS to indicate technical terms relevant to number systems.
} 
(Moravcsik 2017:453)). Further, number is marked using multiple morphological strategies (e.g. suppletion, derivational prefixes, and inflectional prefixes). These differences in pattern and morphological strategies are not random but correspond to natural classes divisible along the animacy hierarchy (Corbett 2000:56). This description of the NOMINAL NUMBER system differs significantly from previous ones, such as Lemi (2010).

Opo also has a semi-productive set of derivational strategies which encode VERBAL NUMBER (Corbett 2000, a.k.a. PLURACTIONALITY, Newman 1990, §3). Just under half of verbs attest a verbal plural stem, and these verbs are divisible into two slightly overlapping groups: a large group which use three morpho-phonemic strategies (i.e. tone modification, vowel gemination, or reduplication) to unpredictably encode either EVENT NUMBER or PARTICIPANT NUMBER (Corbett 2000), and a small group of high-frequency verbs which predictably encode PARTICIPANT NUMBER through lexical strategies (i.e. suppletion or stem alternation). The particulars of the semantics and form of both these groups are heavily dependent on lexical information.

It is important to note that in this paper I differentiate the concepts of VERBAL NUMBER and NOMINAL NUMBER marked on the verb. The latter refers to pronominal agreement markers in Opo (a.k.a. anaphoric clitics (Payne 1997:43)). These are markers which cliticize to the verb and obligatorily agree with the number value of their real-world referents (see §2.4). The former refers to the inherent or derived number of a verb stem, which may affect the semantics of either the number of participants (whether A, S, or O, called PARTICIPANT NUMBER) or the number of events in a verb (called EVENT NUMBER, see §3.1). Due to the significant interaction of these systems it is very difficult to describe the one in isolation from the other (though where possible I do), thus data which contains examples of VERBAL NUMBER will be introduced when I talk about NOMINAL NUMBER in $\S 2$ before it is fully explained in $§ 3$.

\subsection{Data Collection Details}

The data in this paper is from the Bilugu dialect of Opo unless noted (see $\$ 1.4$ on dialect variation). All participants spoke Bilugu fluently, though some identified as ethnically Pame. Participants included Moses Abeba Nyoch, David Onuk Adus, Joshua Otapa Luk, Jeremiah Kadere Akuma, Peter Khora, Jon Gereng Pok, David Oman Pok, Jon Asit Akuma, and James Pintar. Elders who provided recorded texts included Nyoch Abanban, Kwac Jing, Pok Olok, B'asoy Abelbel, and Jul Nikal. Unless otherwise noted, all data is my own. Programs used for data storage and analysis include FLEx, SayMore, and ELAN. Research took place from February 2016 until June 2017 in Addis Ababa and Gambella Regional State, both in Gambella city and the villages of Wankey and Longkwey. Some follow-up research and data checking also took place in 2018 in Gambella.

\subsection{Previous Research}

Opo can rightly be called an understudied language, though surprisingly it has been the topic of several theses and a dissertation. The earliest mentions of Opo in the literature are from Corfield (1938, 1940, cf. Ciita) and later Bender (1976, cf. Shita; 1983a, cf. Opo-Shita; 1983b, 1985, 1994, 1997, 2000, cf. Oро; 2007, 2008, 2010, cf. Ориио), all of which are in the context of broader descriptions of Nilo-Saharan or Koman. The first paper containing significant linguistic data is an analysis of the cardinal numbers of Ethiopian Nilo-Saharan languages by Zelalem (2004), though it is unclear in the paper whether the data was original or sourced from elsewhere. Based on my own 
research I am not confident in the quality of the data presented there, specifically the transcription and glossing. More recently Lemi (2010) did a short Master's thesis on the grammar. A bachelor's thesis on the phonology was done by Van Silfhout (2013a) from Leiden University, which included a collection of the Comparative African Wordlist (2013b). Finally, at the time of this research Mellese was in the process of writing and defending a grammatical description as a $\mathrm{PhD}$. Dissertation at Addis Ababa University (2017).

\subsection{Genetic Classification}

Opo (ISO 639-3 [lgn]) is a language of the Koman family (a.k.a. Coman, from Greenberg 1963), along with Gwama [kmq], Komo [xom], Uduk [udu], and the likely extinct Gule [gly]. Since Greenberg (1963) Koman has commonly been included as a branch or sub-branch of the NiloSaharan phylum. Following Bender (1997), Ethnologue classifies Opo as Nilo-Saharan > SatelliteCore > Core > Koman > Opo (Simmons \& Fennig 2017), see Figure 1.

Figure 1. Opo genetic classification, based on Bender (1997).

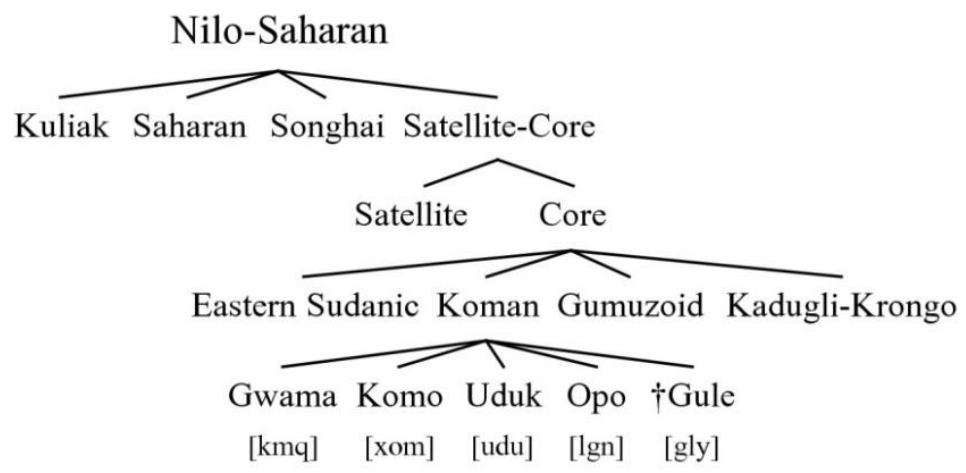

In his historical reconstruction of Nilo-Saharan, however, Ehret (2001) places Koman (including Gumuz [guk]) as a primary split from Proto-Nilo-Saharan. Dimmendaal (2008, 2011, 2014; to appear a, b), however, argues that there is insufficient evidence to claim that Koman (including Gumuz [guk]) is a member of Nilo-Saharan, and so classifies it as an independent phylum (2011:328). Following this model, Glottolog offers the much more conservative classification of Koman > Ориио-Twampa-Komo > Opo (Hammarström et al 2017).

\subsection{Nomenclature and Dialect Variation}

The language classified by the ISO 639-3 code [lgn] and its speakers have been known by many names, primarily by Opo following Bender (1983b, 1985, 1994, 1997, 2000), which was also used by Ehret (2001) and Lemi (2010), but later also by Opuuo (Bender 2007, 2008, 2010), Opuo (Van Silfhout 2013), Upo, Ansita, Ciita, Shiita, Shita, Opo-Shita, Kina, Kwina, and Langa (Simons \& Fennig 2017). In my earlier work (which consisted of mainly unpublished data sets, conference presentations, colloquiums, and personal communications), I added to the chaos by using the names Po for the people group and T'apo for their language. I did so out of respect for the people group, 
since these correspond with the autonyms of the Ethiopian dialects (i.e. Bilugu and Modin, see below), from /p̀̀/ 'people' and /t’á-p̀̀/ 'mouth of people'. According to my Opo informants, names such as Opo, Opuuo, Opuo, and Upo were the result of a misunderstanding. The story goes that a Po man was asked who he was and responded with the word /ò-pò/ 'male (Opo) person'. Other names like Ansita, Shiita, or Ciita are likely derived from the South Sudanese dialects of the language, where /zìtà/ (Pame), and /zìtà Sità/ (Kigile, Pilakoy, likely Bikol), are used as equivalent terms for /pò/ 'people'. Kina and Kwina are possibly derived from Dana, where 'people' is $/ \mathrm{k}^{\mathrm{h}} \mathrm{ìtà} /$ or $/ \mathrm{k}^{\mathrm{h}} \mathrm{ìnà} /$ (cf. singular /díțà/ 'person', which is cognate with the Sudanese dialects for 'people'). The name Langa is a somewhat derogatory term from Anyuak, which unfortunately became the source of the ISO 639-3 code [lgn]. All this considered, I have been persuaded by colleagues and the principles for language naming outlined in Haspelmath (2017) that T'apo and Po are inappropriate names for the dialect cluster in the context of academia, especially given that they are only representative of two of the seven dialects. Therefore, in this and future work I will refer to the language as Opo, following the precedent of Bender (1983b).

As has been alluded to above, Opo is not a single language variety but rather a cluster of varieties. This has been recognized as far back as Corfield's notes, which describe three dialect groups of Ciita, namely Kusgilo, Kigile, and Buldiit (1938:129-130). Bender recognized dialect differences between the Ethiopian and Sudanese varieties in many of his works (e.g. 1983:260). More recently, Lemi identifies seven dialects based on an uncited survey: Pilak'oye, Dana, Pame, Kigile, Bikol, Moudin, and Bilogo (2010:1). Similarly, Van Silfhout identified two Ethiopian varieties - Modi and Bilogo — and five South Sudanese varieties — Pame, Kigoli, Pilagoj, Bigol and Dana (2011:8) — based on information from her informant, a Modin speaker. Mellese also notes these seven dialects Mudin, Bilugu, Pame, Kigile, Pilakoj, Bikol, and Dana (2017:2-3).

In my own research, utilizing both data collection and interviews, I have likewise tentatively identified seven dialects of Opo: Bilugu and Modin in Ethiopia, and Pame, Kigile, Pilakoy, Bikol, and Dana in South Sudan. These are outlined in Table 1, including information on the current location of speakers. Autonyms are given based on the Bilugu dialect. 
Table 1. Contemporary dialects of Opo.

\begin{tabular}{|c|c|c|c|}
\hline Region & Dialect & Autonym & Spoken in \\
\hline \multirow[t]{2}{*}{ Ethiopia } & Bilugu & /búlúgū/ & $\begin{array}{l}\text { Wanke and Langkwe (Gambella, Ethiopia). Populations found } \\
\text { in the Akula refugee camps (Gambella, Ethiopia). Formerly } \\
\text { inhabited Pagak, Kalkis, and Wipwiya (exact locations } \\
\text { uncertain). }\end{array}$ \\
\hline & Modin & /mòdìn/ & $\begin{array}{l}\text { Mera and Atuch (Atus) (Gambella, Ethiopia). Formerly in } \\
\text { Wanke (Gambella, Ethiopia). }\end{array}$ \\
\hline \multirow{5}{*}{$\begin{array}{l}\text { South } \\
\text { Sudan }\end{array}$} & Pame & /pāmé/ & $\begin{array}{l}\text { Mayut (both Amahot and Mayut, South Sudan). Some found in } \\
\text { the Akula refugee camp (Gambella, Ethiopia). }\end{array}$ \\
\hline & Kigile & /kî́gīlé/ & $\begin{array}{l}\text { Kigile (South Sudan). Some found in the Akula refugee camp } \\
\text { (Gambella, Ethiopia). }\end{array}$ \\
\hline & Pilakoy & /pílák’ój/ & $\begin{array}{l}\text { Katen (South Sudan). Some found in the Akula refugee camp } \\
\text { (Gambella, Ethiopia). }\end{array}$ \\
\hline & Bikol & /bīkòl/ & $\begin{array}{l}\text { Paytet (South Sudan). Some found in the Tongo refugee camp } \\
\text { (Benishangul-Gumuz, Ethiopia). }\end{array}$ \\
\hline & Dana & /dàná/ & $\begin{array}{l}\text { Dajo (South Sudan). Some found in the Akula refugee camp } \\
\text { (Gambella, Ethiopia) and Tongo refugee camp (Benishangul- } \\
\text { Gumuz, Ethiopia). }\end{array}$ \\
\hline
\end{tabular}

From the minimal comparative data I have been able to collect, as well as anecdotal evidence from my Bilugu, Pame, and Dana speaking informants, the dialect cline appears to follow the order in which I present them: Bilugu, Modin, Pame, Kigile, Pilakoy, Bikol, and finally Dana. Table 2 below gives a small example set of data illustrating this.

Table 2. Comparative data of Opo dialects. ${ }^{2}$

\begin{tabular}{|c|c|c|c|c|}
\hline & 'people' & $\begin{array}{l}\text { 'He went home' } \\
\text { 3sG.M.NOM=go.SG } \\
\text { home }\end{array}$ & $\begin{array}{l}\text { 'He ate food' } \\
\text { 3sG.M.NOM=eat.SG } \\
\text { food }\end{array}$ & $\begin{array}{l}\text { 'He saw a dog' } \\
\text { 3sG.M.NOM=see dog }\end{array}$ \\
\hline Bilugu & pò & $\bar{a} r=$ fà pà & àr = sá mà & $\bar{a} r=$ gìl tènè \\
\hline Modin & pò & ār = fà wùpà & ār = sá mà & $\bar{a} r=$ gìl tèjn \\
\hline Pame & zìtà & ār = zà pà & ār = sá mà & $\bar{a} r=$ gìl tèjn \\
\hline Kigile & Sìtà & àr = fà wàt & ār = sá mà & ār = gìl tèn \\
\hline $\begin{array}{l}\text { Pilako } \\
\text { y }\end{array}$ & Sìtà & 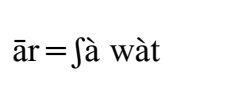 & - & $\bar{a} r=$ gìl tèn \\
\hline Bikol & - & - & - & - \\
\hline Dana & dítà $\sim \mathrm{k}^{\mathrm{h}} \mathrm{ìtà}$ & hār = dā wád & hār = úfā mà & hār = Jílá tì̀̀y \\
\hline
\end{tabular}

\footnotetext{
${ }^{2}$ Kigile and Pilakoy data in this table are reported forms by Bilugu and Pame speakers.
} 
From these data it remains to be seen whether Kigile and Pilakoy attest any significant linguistic differences. Also, the complete absence of data from Bikol makes it impossible to judge its status as a distinct dialect and its position along the cline. According to my informants, however, it is somewhat closer to Dana than to Pame, Kigile, and Pilakoy. Of all the dialects, Dana is the most distinct, and further research may prove it to be an independent language. Otero (2016, forthcoming) argues this, showing that Corfield's Buldiit dialect (1938) is in fact Dana, and claiming that it is unlikely to be mutually intelligible with other Opo varieties.

As previously stated, this paper describes the number system of the Bilugu dialect of Opo, which is one end of the dialect cline. In certain cases I offer comparative data from Pame, Modin, and Dana.

\subsection{Phonological Overview}

Given that Opo is a significantly understudied language, it is useful here to provide an overview of the phonology. While phonological analyses may be found in Lemi (2010) and Van Silfhout (2013a), my analysis differs significantly from these, especially with regard to vowel phonemes and tone. The following is based off of data primarily from the Bilugu, Modin, and Pame dialects, and is not representative of Dana.

Depending on the variety, Opo has upwards of thirty-two phonemic consonants. Table 3 below gives a complete chart of these phonemes, with uncertain phonemes or those not attested across all dialects given in parentheses.

Table 3. Phonemic consonants of Opo (excluding Dana).

\begin{tabular}{|c|c|c|c|c|c|c|}
\hline & & BILABIAL & $\begin{array}{c}\text { ALVEOLA } \\
\text { R }\end{array}$ & PALATAL & VELAR & GLOTTAL \\
\hline \multirow{5}{*}{ Stop } & \multirow{5}{*}{$\begin{array}{l}\text { vl. } \\
\text { vl. aspirated } \\
\text { vl. ejective } \\
\text { vd. } \\
\text { vd. } \\
\text { implosive }\end{array}$} & $\mathrm{p}$ & $\mathrm{t}$ & $\mathrm{c}$ & $\mathrm{k}$ & (?) \\
\hline & & $\mathrm{p}^{\mathrm{h}}$ & $\mathrm{t}^{\mathrm{h}}$ & $\left(\mathrm{c}^{\mathrm{h}}\right)$ & $\mathrm{k}^{\mathrm{h}}$ & \\
\hline & & p' & $\mathrm{t}^{\prime}$ & $c^{\prime}$ & $\mathrm{k}^{\prime}$ & \\
\hline & & $\mathrm{b}$ & d & $\mathrm{f}$ & $\mathrm{g}$ & \\
\hline & & 6 & d & & & \\
\hline Fricative & vl. & & S & $\left(\int\right)$ & & $\mathrm{h}$ \\
\hline Nasal & vd. & $\mathrm{m}$ & $\begin{array}{c}\text { (2) } \\
\mathrm{n}\end{array}$ & $\mathrm{n}$ & $\eta$ & \\
\hline Lateral & vd. & & 1 & & & \\
\hline Trill & vd. & & $\mathrm{r}$ & & & \\
\hline Semivowel & $\begin{array}{l}\text { vd. } \\
\text { vl. }\end{array}$ & $\begin{array}{l}\mathrm{W} \\
(\mathrm{M})\end{array}$ & & $\mathrm{j}$ & & \\
\hline
\end{tabular}

The palatal stops $/ \mathrm{c}, \mathrm{c}^{\prime}, \mathrm{f} /$ in Bilugu have various phonetic realizations ranging from [c $\left.\sim \mathrm{t} \int\right],\left[\mathrm{c}^{\prime} \sim \mathrm{t} \int^{\prime}\right]$

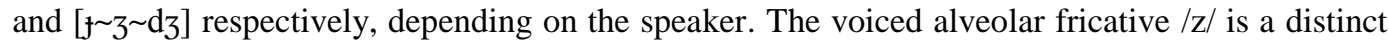
phoneme in Pame, but has merged with $/ \mathfrak{y} /$ in Bilugu and Modin. The glottal stop / $/$ and voiceless aspirated palatal stop $/ \mathrm{c}^{\mathrm{h}} /$ are uncertain phonemes because they have only been observed as contrastive at morpheme boundaries, though / $/$ does show up lexically before semivowels in a 
handful of nouns and verbs such as /Pwáj/ 'wild dog' and /Pjá/ 'go PL'. The voiceless palatal fricative $/ \mathrm{S} /$ is an allophone of /s/ before the high +ATR vowels in Bilugu, Modin, and Pame, but its status is uncertain in the other dialects (though it is known to be phonetically present at least). The voiceless labio-velar semivowel $/ \mathrm{M} /$ is a distinct phoneme in Bilugu and Modin, but its status in the other dialects is uncertain.

Opo has a seven-vowel system, which is common for Koman languages. ${ }^{3}$ These pattern as a /2IU/ system (Casali 2008:504, 2016:95), with ATR contrast in the high vowels only, leaving the mid and low vowels as phonologically [-ATR]. Phonetically, the mid -ATR vowels $/ \varepsilon / \mathrm{and} / \mathrm{s} /$ tend to be quite high, sounding almost like [e] and [o], or [ع] and [o]. In addition, Bilugu, Modin, and

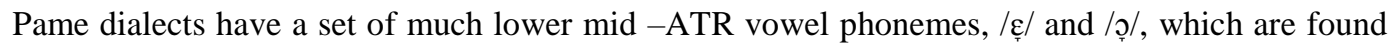
almost exclusively in words borrowed from Anyuak and Nuer, and only in CVC environments (e.g.

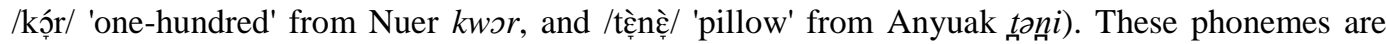
presumably "foreign", having arisen through contact and being reserved for borrowed terms, and thus are not considered part of the original vowel system. The full inventory is illustrated in Table 4 below. Note that while vowel length is contrastive, I do not consider long-vowels to be distinct phonemes, thus they are excluded from this chart. Throughout this paper I will use double letters to represent vowel length instead of the IPA length marker (e.g. /aa/ instead of /a:/).

Table 4. Phonemic vowels of Opo (excluding Dana).

\begin{tabular}{|c|c|c|}
\hline & FRONT & BACK \\
\hline HIGH [+ATR] & $\mathrm{i}$ & $\mathrm{u}$ \\
\hline HIGH [-ATR] & I & $U$ \\
\hline \multirow{2}{*}{ MID [-ATR] } & $\varepsilon$ & 0 \\
\hline & $(\varepsilon$ & (ָָ) \\
\hline LOW & & \\
\hline
\end{tabular}

Tone in Opo has a high lexical and grammatical functional load. According to my analysis there are four levels of phonemic tone in Bilugu: low (L), mid (M), high (H), and extra-high (X). Extrahigh is attested only on a subset of the vowels: / $\mathrm{i} \mathrm{a} /$. The number of phonemic tone levels in the other dialects has not been fully analyzed, but based on current data there are possibly only three. Table 5 below gives evidence of four levels of contrast on monosyllabic, monomorphemic nouns in a M_H environment, using the frame /tā _ tón/ 'It is a big _ '. The pitch contour diagrams are modeled on Snider (1999, 2017), and represent relative phonetic pitch heights of an utterance. Like many languages with large tone inventories, the surface realization of lexical tone in Opo is highly stable.

\footnotetext{
${ }^{3}$ Chali Uduk is the exception, having only five phonemic vowels (Killian 2015:32). Evidence of a seven vowel system in Gwama can be found in Hellenthal \& Kutch-Lojenga (2011), and for Komo in Olejarczuk et al $(2016,2019)$.
} 
Table 5. Lexical tone contrast in Opo (Bilugu only).

\begin{tabular}{|c|c|c|c|c|}
\hline Lexical tone & $\mathrm{L}$ & $\mathrm{M}$ & $\mathrm{H}$ & $\mathrm{X}$ \\
\hline Pitch Contour & {$\left[\begin{array}{c}- \\
-\end{array}\right]$} & {$\left[-^{-}\right]$} & {$\left[-^{--}\right]$} & {$\left[\begin{array}{l}- \\
-\end{array}\right]$} \\
\hline $\begin{array}{l}\text { Data } \\
\text { Gloss } \\
\text { Translation }\end{array}$ & $\begin{array}{l}\text { tā pì tón } \\
\text { BE cow big } \\
\text { 'It is a big cow.' }\end{array}$ & $\begin{array}{l}\text { tā fo tón } \\
\text { BE snake big } \\
\text { 'It is a big snake.' }\end{array}$ & $\begin{array}{l}\text { tā pé tón } \\
\text { BE snake.sp big } \\
\text { 'It is a big snake.' }\end{array}$ & $\begin{array}{l}\text { tā } \mathbf{k}^{\text {ḥ̌ }} \quad \text { tón } \\
\text { BE mouse.sp big } \\
\text { 'It is a big mouse.' }\end{array}$ \\
\hline
\end{tabular}

\section{Nominal Number in Bilugu Opo}

In this section I describe NOMINAL NUMBER in Bilugu Opo as it is marked on both the noun and the verb stem. I begin by differentiating the two number systems $(\$ 2.1)$ following the terminology of Corbett (2000). I proceed to describe the TOP SYSTEM which applies to human referents (HR) (\$2.2), and then the SECOND SYSTEM which applies to non-human referents (NHR) (§2.3). For each of these systems I demonstrate the different means by which number is or is not expressed on nominals (e.g. morphological or lexical, inflectional or derivational). In this I also show that all four logical patterns of number expression noted by Moravcsik are attested: marked singular and plural, unmarked singular and plural, marked plural, and marked singular (2017:453). Finally, I show how these two number systems are marked on the verb stem $(\$ 2.4)$, specifically in the form of pronominal agreement markers (a.k.a. anaphoric clitics).

\subsection{Two Systems of Nominal Number}

Bilugu Opo has two number systems, meaning that there are two natural classes of nominals having different available number oppositions. In accordance with the typological predictions of Corbett (2000), these systems split along the animacy hierarchy (Figure 2). This hierarchy includes natural grammatical and semantic classes of nominals: first person pronouns, second person pronouns, third person pronouns, kinship terms (e.g. mother, cousin), nouns referring to humans (e.g. man, worker), nouns referring to animate non-humans (e.g. dog, snake), and nouns referring to inanimate nonhumans (e.g. rock, chair, love).

Figure 2. The Animacy Hierarchy (Corbett 2000:56).

$1^{\text {st }}$ person $>2^{\text {nd }}$ person $>3^{\text {rd }}$ person $>$ kin $>$ human $>$ animate $>$ inanimate

Corbett predicts that when there are multiple number systems in a language (i.e. multiple sets of available number oppositions such as GENERAL NUMBER, singular $\sim$ plural, or single $\sim$ plural $\sim$ dual) they will divide at some point along this hierarchy. At a given split, the left system will have more available number oppositions than the right. Thus, if there is a singular $\sim$ plural opposition available for nouns referring to humans in a given language, Corbett predicts it will also be available for kinship terms and pronouns. Likewise, if there is no singular plural opposition for nouns referring to humans, there will be none for nouns referring to non-humans. The one exception to this pattern 
is that the third person pronouns may split internally if there is a split lower down in the hierarchy. That is, third person pronouns referring to nominals to the left of the split will attest the same number opposition, but those referring to nominals to the right of the split may pattern either with the left or right nominals (2000:62). Corbett also predicts that if there is morphological irregularity in marking number, greater irregularity will occur leftward in the hierarchy (2000:76).

For Bilugu Opo the split occurs between human and non-human nominals. Following the terminology of Corbett, I will call these two systems the TOP SYSTEM and the SECOND SYSTEM (2000). The TOP SYSTEM applies to pronouns, kinship terms, and humans, showing a basic opposition between singular and plural. The SECOND SYSTEM applies to all non-humans - both animate and inanimate, and their referring pronouns - and attests GENERAL NUMBER, meaning nominals can be expressed without reference to number (see §2.3). Figure 3 below illustrates how the two systems are divided along the animacy hierarchy, whereas Figure 4 illustrates the available number oppositions for the two natural classes of Bilugu Opo nominals. These figures are modeled after those found in Corbett (2000).

In Figure 3 the animacy hierarchy is given at the top and the division of number systems along the bottom. The number values in addition to singular / general are given in the leftmost column (in the case of Bilugu Opo there is only plural, no dual or paucal). The dashed line indicates attestation of a number value for nominals with respect to the animacy hierarchy.

Figure 3. The top and second nominal number systems of Bilugu Opo.

\begin{tabular}{|c|c|c|c|c|c|c|c|}
\hline & \multicolumn{7}{|c|}{ Animacy Hierarchy } \\
\hline & 1 & 2 & 3 & kin & human & animate & inanimate \\
\hline \multirow[t]{2}{*}{ Range of Plural } & \multicolumn{5}{|c|}{ 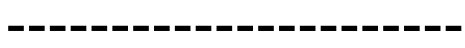 } & \multirow{2}{*}{\multicolumn{2}{|c|}{ Second System }} \\
\hline & \multicolumn{5}{|c|}{ Top System } & & \\
\hline
\end{tabular}

Figure 4 is based on Corbett's derivation of number oppositions (2000), illustrating how singular $\sim$ plural opposition is available for human nominals, but is unavailable for non-human nominals (i.e. it is not that only singular is available for non-humans, but rather that neither singular nor plural are available). This figure may seem upside down, since human referents belong to the TOP SYSTEM, however "top" refers to the left side of the animacy hierarchy, which does not enter into this diagram.

Figure 4. Available number oppositions for Bilugu Opo nominals.

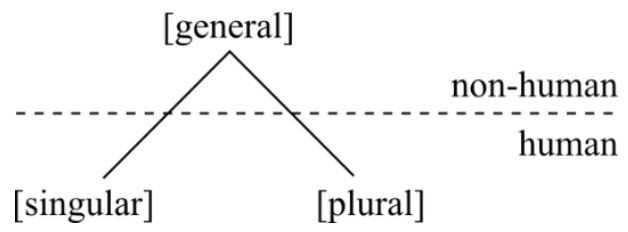




\subsection{The Top System: Human Referents}

The TOP SYSTEM of Bilugu Opo encompasses all human referent (HR) nominals and maintains a basic opposition between singular and plural. Number is obligatory and is expressed through one of three morphological strategies: suppletion, derivational morphology, or inflectional morphology. These strategies correspond to three natural divisions of the animacy hierarchy: pronouns, general human referents, and kinship terms. In the following subsections I describe these three groups in detail.

2.2.1 Pronouns: Number Marking via Suppletion. The first group are the HR pronouns. Like most pronominal systems in the world the Bilugu Opo pronoun system encodes number through suppletion (Corbett 2000:155). This means that pronouns with differing number values each have their own unique lexical base; one is not derived from the other by some morphological means. Here, and also with the derivational markers (\$2.2.2), the singular is "cumulatively expressed" (Moravcsik 2017:454) or "simultaneously expressed" (Stump 1998:27) with gender, meaning they are inseparable or even conflated. A chart of the independent pronouns is given in Table 6, including their corresponding vocative forms.

Table 6. Bilugu Opo independent pronoun chart.

\begin{tabular}{|c|c|c|}
\hline & INDEPENDENT / BASE & $\operatorname{VOC}(\mathrm{M} / \mathrm{F})$ \\
\hline $1 \mathrm{SG}$ & $\bar{a} g \bar{a}$ & - \\
\hline $2 \mathrm{SG}$ & $\bar{a} j$ & āj, ùrà / bā \\
\hline 3SG.M & *ùtà & - \\
\hline 3SG.F & *6ā & - \\
\hline 1PL.INCL & mìnà & - \\
\hline 1PL.EXCL & mànà & - \\
\hline 2PL & $\bar{u} m a \bar{~}$ & $\bar{u}$ mà \\
\hline 3PL & *bìjà & - \\
\hline
\end{tabular}

The third person pronouns $/ *$ ùtà/, /*6ā/, and /*bìjà/ are starred $(*)$ to indicate that they are not attested in isolation, but rather form the base of various independent forms. In discourse they invariably occur with a modifier such as a demonstrative enclitic, the associative suffix, or the relativizing enclitic /=mó/.

The examples below illustrate the suppletive singular and plural forms of the pronouns using the frame /tā _ / 'it is _ _, in answer to the question 'Who did it?'. ${ }^{4}$ Note that the first person (1) and second person pronouns (2) correspond directly to some forms of the pronominal agreement markers given in Table 12, §2.4. Note also that the third person pronouns are given with the medial demonstrative enclitic / = (î)nī/, which is a common means of expressing them as free words. The derivations of all three demonstrative forms for the masculine, feminine, and plural pronouns are given in Table 7.

\footnotetext{
${ }^{4}$ In these examples and throughout the paper I use bold font to draw attention to particular morphemes.
} 
(1) First person singular $\sim$ plural pronouns
a. tā $\bar{a} g \bar{a}$
BE 1SG
b. tā mànà
BE 1.PL.EXCL
'It is I.'
'I it us (excluding addressee).'
c. tā mìnà
BE 1PL.INCL
'It is us (including addressee).'

(2) Second person singular $\sim$ plural pronouns
a. tā $\bar{a} y$
BE 2SG
b. tā ūmā
BE 2PL
'It is you (SG).'
'It is you (PL).'

(3) Third person singular plural pronouns
a. tā ờténī
BE 3SG.M:MED
b. tā bénī
BE 3SG.F:MED
'It is him (there).'
'It is her (there).'

\section{c. tā bìjénī \\ BE 3PL:MED}

'It is them (there).'

Table 7. Derivations of Bilugu Opo human third person demonstrative pronouns.

\begin{tabular}{|c|c|c|c|}
\hline & PROXIMAL & MEDIAL & DISTAL \\
\hline SG.M & $\begin{array}{l}\text { ùtén̄̄ } \\
\text { ùtà =(Î)n̄̄ } \\
\text { 3sG.M=PROX }\end{array}$ & 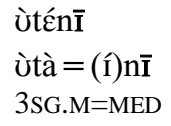 & 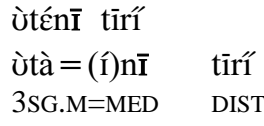 \\
\hline SG.F & $\begin{array}{l}\text { 6én̄̄ } \\
6 \bar{a}=(\hat{I}) n \bar{\jmath} \\
\text { 3sG.F=PROX }\end{array}$ & 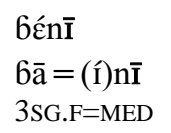 & 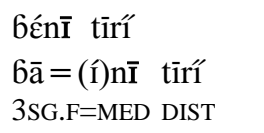 \\
\hline PL & $\begin{array}{l}\text { bìjén̄̄ } \\
\text { bìjà = (î)n̄̄ } \\
\text { 3PL=PROX }\end{array}$ & $\begin{array}{l}\text { bìjén̄i } \\
\text { bìjà }=(\hat{I}) n \overline{\mathbf{I}} \\
\text { 3PL=MED }\end{array}$ & 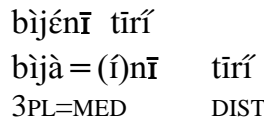 \\
\hline
\end{tabular}

2.2.2 Human Referent Nouns: Number Marking via Derivation. The second group includes the vast majority of HR nouns in Bilugu Opo, excluding only kinship terms, and encodes number via derivational means sourced in the third person pronoun bases just shown: /ùtà/ '3SG.M' /6ā/ '3SG.F', and /bìjà/ '3PL'. 
One means is to derive HR nouns by using the pronoun bases in an associative construction with another noun. The associative construction in Bilugu Opo is the basic $\mathrm{N}+\mathrm{N}$ modifying relationship, schematized in (4). The first element takes the associative prefix /-(î)/ and modifies the second to the effect of 'noun of noun' (4)a) or sometimes forming a compound (4)b). Note that the $/ \mathrm{I} / \mathrm{of}$ this suffix is elided when affixed to a vowel, leaving only the $\mathrm{H}$ tone.

(4) The associative construction
a. $\mathrm{N} \quad \mathrm{N} \rightarrow \mathrm{N}+\mathrm{N}$

kògò-(Î) wàc’à kògó wàc’à
b. $\mathrm{N} \quad \mathrm{N} \rightarrow \mathrm{N}$
wàc’à-(î) kògò wàc’á-kògò
fish-ASC scale fish:ASC-scale
'Scale of fish'
'Scalefish (a class of fish)'

For deriving HR nouns, the third person pronoun bases take the first slot in the associative construction. This is illustrated with the noun / Màr/ 'spirit' to derive the term 'spiritist' in (5), with /k'óc's/ 'land, soil' to derive 'landowner' in (6), and with the proper noun /îtjópjà/ 'Ethiopia' to derive 'Ethiopian' in (7). In each of these cases the number value is encoded in the pronoun base used to derive the human nominal.

(5)

a. ̀tá-Màr
3sG.M:ASC-spirit

'Spiritist (M)'

(6)

a. ̀̀tá-k’óc’ó

3SG.M:ASC-land

'Landowner (M)'

(7)
a. ̀̀tá-ìtjópjà
3sG.M:ASC-Ethiopia
b. 6á-ìtjópjà
3sG.F:ASC-Ethiopia
c. bìjá-ìtjópjà
3PL:ASC-Ethiopia
'Ethiopian (M)'
'Ethiopian (F)'
c. bìjá-Màr
3PL:ASC-spirit
'Spiritists'
b. 6á-k’óc’ó
3SG.F:ASC-land
c. bìjá-k'ác’ó
3PL:ASC-land
'Landowners'

Another common means of encoding number utilizes three derivational prefixes - ì-/ 'SG.M', /6ā-/ 'SG.F', and /bì-/ 'PL' — which are clearly reduced forms of the third person pronoun bases. These are organized in Table 8 below.

Table 8. Bilugu Opo human number-gender derivational prefixes.

\begin{tabular}{|c||c|c|}
\hline & SG & PL \\
\hline \hline M & Ù- & \multirow{2}{*}{ bì- } \\
\cline { 1 - 2 } F & bā- & \\
\hline
\end{tabular}

These prefixes can be used for a kind of participant nominalization (Payne 1997:225), attaching directly to verb stems to derive a nominal corresponding to the A or S (nominative) argument of a verb. The result is a term for the "one who does [verb]" or "one who is [verb]", as in (8) below. As 
with the associative derivations, the number value of the resulting noun in these examples is encoded entirely in the derivational prefixes.

(8) HR nouns derived from verb roots
a. càní 'send'
bā-càní $\quad$ 'sender (F)'
bì-càní 'senders' Ù-càní 'sender $(\mathrm{M})^{\prime}$
b. $\mathrm{k}^{\mathrm{h}} \overline{\mathrm{a} j \mathrm{i}} \quad$ 'herd (v.)'
Ù-k $\mathrm{k}^{\mathrm{h}} \mathrm{aj}$
bā-k $\mathrm{k}^{\mathrm{h} j \mathrm{j}}$ ' 'herdswoman'
bì-k ${ }^{\mathrm{h}}$ ājí $\quad$ 'herdsmen'

Note that these are not simply relative clauses. True relative clauses in Bilugu Opo utilize the full pronoun base plus the relativizing clitic $/=$ mó/, as in (9)a), and can take verbal inflectional morphology such as the future-irrealis marker /á/, as in (9)b). Attempting to add such inflectional morphology to a participant nominalization is ungrammatical, as in (10).

(9) Grammatical relative clauses
a. $\quad$ bā=mú càní $=\bar{a} \mathbf{r}$
3SG.F=REL send=3M.ACC
b. bā=mú á-càní=ār
3SG.F=REL FUT-Send=3M.ACC

'She who sent him.'

'She who will send him.'

(10) Ungrammatical HR participant nominalization

*6ā-á-càní

*SG.F-FUT-send

*'She who will send.'

Verbal derivational morphology or incorporated objects, on the other hand, may remain on the verb stem when deriving such a nominal. For example, when a deictic directional (DD) marker is used to modify the goal of a motion verb — as in (11) where /càní/ 'send' takes /-ú/ 'DD1' to the change the goal to the deictic center (i.e. 'send here') - the derived stem can become the base of nominal derivations (12).

(11) Verb with the deictic directional suffix

ùténī càn-ú $=\bar{a} b$

3SG.M:MED send-DD1=3SG.F.ACC

'He sent her here.'

(12) HR participant nominalization of derived verb stem

Ù-càn-ú

SG.M-send-DD1

'Sender (M), one who sends here (towards deictic centre).'

As will be explained thoroughly in $\S 3$, many verbs in Opo attest a derived verbal plural stem (a.k.a. PLURACTIONAL). When the number-gender prefixes are used to derive nominals from such 
verbs, they take the appropriate stem. For example, in (13)a) the verbal adjective /c'í/ 'be black' takes a reduplicated form / $\mathbf{c}^{\prime} \overline{1} \sim \mathrm{c}^{\prime} \mathbf{i} /$ as its plural stem. When a masculine or feminine singular nominal is derived it takes the singular stem to form /ù-c'í/ 'black man' or / $6 \bar{a}-c^{\prime \prime}$ '́/ 'black woman', whereas the plural takes the reduplicated stem to form /bì-c'ī c'̌́l/ 'black people'. ${ }^{5}$ Similarly in (13)b) the verbal adjective /tón/ 'be big (SG)' has a suppletive plural form /cègè/ 'be big (PL)'. Again, when the masculine or feminine singular is derived it takes the singular stem, whereas when the plural is derived it takes the plural stem.

(13) HR nouns derived from verbs with contrastive singular $\sim$ plural stems

\begin{tabular}{|c|c|c|c|}
\hline a. c'r & 'be black' & b. tón & 'be big' \\
\hline$c^{\prime} \overline{1} \sim c^{\prime} 11$ & 'be black (PL)' & cغ̀gè & 'be big (PL) \\
\hline ù-c'í & 'black man' & ù-tón & 'elder (M)' \\
\hline bā-c'í & 'black woman' & bā-tón & 'elder (F)' \\
\hline bì-c'ī c c'í & 'black people' & bì-cèg દ̀ & 'elders' \\
\hline
\end{tabular}

Yet another derivational strategy for expressing number involves a small set of HR nouns with an unmarked plural root to which the singular number-gender prefixes can be added, as in (14). These nouns correspond to classes of people, such as the word for 'people' itself Error! Reference source not found.a), youth (14)b), proper names for ethnic groups (14)c-d), and even soldiers (14)e). Unlike those HR nouns derived using the full pronoun base - described in (5), (6), and (7) - these nouns are not formed using an associative construction, but directly affix to the noun. ${ }^{6}$

(14) HR nouns with plural base and derived singular forms.
a. pò
ù-p̀̀
'people' / the Opo'
'man' / Opo man'
6ā-pò
'woman' / Opo woman'
b. $\mathrm{p}^{\mathrm{h}} \overline{\mathrm{a}} \mathrm{l}$
ù-p ${ }^{\mathrm{h}} \bar{l}$
'young people'
bā-ph $\bar{a}^{\mathrm{l}}$
'young man'
'young woman'
c. łānó
'Nuer people'
Ù-łāyó
'Nuer man'
6ā-fāyó
'Nuer woman'
d. pāw
Ù-pāw
bā-pāw
'Habesha people'
'Habesha man'
'Habesha woman'
e. déc 'soldiers, army'
ù-déc 'soldier (M)'

Finally, there are three HR nouns that encode number through suppletive singular $\sim$ plural pairings, most of which are likely lexicalizations of the derivational number-gender prefixes. These are the terms for 'male', 'female', and 'child', given in (15) below.

(15) HR nouns with suppletive plurals
a. ùkày kày
'male husband'
b. àdím $\bar{\varepsilon}$
'child'

\footnotetext{
${ }^{5}$ Note here that the prefix / $\mathrm{u}-/$ assimilates the $[+\mathrm{ATR}]$ value of the verb root vowel.

${ }^{6}$ Interestingly, as a feminine singular for the term 'soldier' in (14)e), my informants produced /6á-déc/ SG.F:ASC-army 'woman of the army', rather than $/ * 6 \bar{a}-\mathrm{d} \varepsilon \dot{c} /{ }^{*}$ SG.F-army 'female soldier'. Presumably, this is because the term is semantically marked, their tradition being that females do not engage in warfare.
} 
bày 'males, husbands' bìtí $\quad$ 'children'

c. Gāph à 'female, wife'

$\overline{\mathrm{s}} \mathrm{p}^{\mathrm{h}} \overline{\mathrm{J}} \quad$ 'women'

Looking at cognate forms across other Opo dialects and Koman languages helps explain these forms (see Table 9 below). The word /ùkày/ 'male' (cf. /kày/ 'husband') is composed with the masculine prefix /ù-/ plus the root /kàj/. The plural/bàj/ thus appears to be a phonological reduction of the plural prefix /bì-/ and the same root /*bì-kàj/ $\rightarrow$ /bàj/. The word /6āphà/ 'woman' is clearly related to the feminine pronoun base $/ \bar{b} \bar{a} /$, plus a fossilized element $/{ }^{*} \mathrm{p}^{\mathrm{h}} \mathrm{a} /$ which corresponds to a second bilabial consonant in cognate forms. The source of its plural $/ \overline{\mathrm{o}} \mathrm{p}^{\mathrm{h}} \overline{\mathrm{\jmath}} /$ is likely a very old lexical plural, given its cognates. The plural /bìt'́/ 'children' appears to be a combination of the plural prefix /bì-/ plus a fossilized root $/{ }^{*}$ t'̂́l, likely derived from a Proto-Koman root meaning 'child' (cf. the

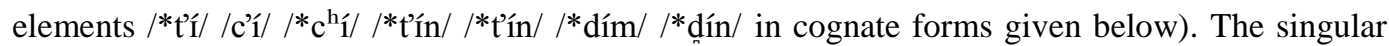
form /àdím $\bar{\varepsilon} /$ 'child' is thus likely composed of this element plus a lexicalized historical prefix /*à$1 .^{7}$

Table 9. Cognates for suppletive singular plural noun pairing in other Opo dialects and Koman languages. Data for Komo from Manuel Otero (2015a, 2015b, p.c.), for Uduk from Don Killian $\left(2015,2018\right.$, p.c.), and for Gwama from Justin Goldberg (p.c.). ${ }^{8}$

\begin{tabular}{|c|c|c|c|c|c|c|c|c|}
\hline & \multicolumn{4}{|c|}{ Opo } & \multirow{2}{*}{$\begin{array}{c}\text { Komo } \\
\text { Ethiopian } \\
\end{array}$} & \multirow{2}{*}{$\begin{array}{l}\text { Uduk } \\
\text { Chali } \\
\end{array}$} & \multirow{2}{*}{$\begin{array}{l}\text { Gwama } \\
\text { Lowland } \\
\end{array}$} \\
\hline & & Bilugu & Modin & Pame & Dana & & & \\
\hline 'husband' & SG & kàj & kày & kày & kàz & gàz & à = kát ${ }^{\mathrm{h}}$ & - \\
\hline \multirow{2}{*}{$\begin{array}{l}\text { 'man, } \\
\text { male' }\end{array}$} & SG & ùkàj & ùkày & ùkày & jékàz & \multirow{2}{*}{$\begin{array}{c}\mathrm{j} \overline{1}=\mathrm{gwàz} \\
\text { gwaz }\end{array}$} & \multirow{2}{*}{$\begin{array}{c}\text { wàtín gwàt }{ }^{\mathrm{h}} \\
{ }^{*} \text { gwàt }^{\mathrm{h}}\end{array}$} & \multirow{2}{*}{$\begin{array}{c}\text { kíkīzì } \\
\text { mā=kíkīzì }\end{array}$} \\
\hline & PL & bày & bày & bày & kwàz & & & \\
\hline 'wife' & SG & \multirow{2}{*}{ bāph ${ }^{\mathrm{h}} \mathrm{a}$} & \multirow{2}{*}{ bāphà } & \multirow{2}{*}{ bāppà } & \multirow{2}{*}{ Gàp’à } & \multirow{2}{*}{ bāmít } & \multirow{2}{*}{ à = 6óm } & wùpí \\
\hline \multirow{2}{*}{$\begin{array}{l}\text { 'female, } \\
\text { woman' }\end{array}$} & SG & & & & & & & - \\
\hline & PL & $\bar{\jmath} p^{\mathrm{h}} \bar{\jmath}$ & $\bar{\jmath} p^{\mathrm{h}} \bar{\jmath}$ & $\bar{\jmath} p^{h}$ & $\overline{\mathrm{\rho}} \mathrm{p}^{\mathrm{h}}$ & $\bar{u} p$ & $\overline{\mathrm{u}} \mathrm{p}^{\mathrm{h}}$ & - \\
\hline \multirow{2}{*}{ 'child' } & SG & àdím $\bar{\varepsilon}$ & àdím & àdím & àdín & āt & à = c'í? & wāl ? \\
\hline & PL & bìt'í & bìt’í & bìt'í & wàt'ín & Swàt'ín & $\overline{\mathrm{u}} \mathrm{c}^{\mathrm{h}} \hat{1}$ ? & - \\
\hline
\end{tabular}

2.2.3 Kinship Terms: Inflectional Number. The final group of HR nominals roughly corresponds to kinship terms, but also includes some human offices like /àt'äp'ú/ 'king'. These mark number via an inflectional prefix: the singular form remains unmarked for number while the

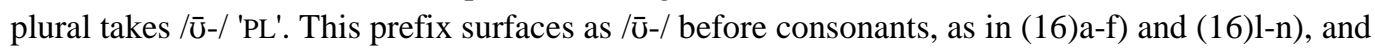

\footnotetext{
${ }^{7}$ This /*à-/ may have the same source as the non-human pronoun base /*hà/ '3NH' and derivational prefix /à-/ 'NH' found with NHR nouns (see §2.3.3-4), and may be related to the Class 2 gender proclitic /à = / found in Uduk (see Killian 2018).

${ }^{8}$ In Table 9 the dashed line represents a semantic split in the singular; words centered on the line encompass both glosses. Single dashes (-) indicate that the corresponding word is not cognate. A question mark (?) indicates a questionable cognate. Chali Uduk $/ *^{\text {gwàt }} \mathbf{t}^{\mathrm{h}} /$ is starred because it does not appear as an independent plural form, but does appear in the attributive nominative /gwàt $t^{\mathrm{t}} \bar{a} \mathrm{n} /$ 'male'.
} 
as /w-/ before vowels, as in (16)g-k). Note that many of these kinship terms are inalienably possessed and that this is reflected in the gloss by the default third singular possession, as in (16)cd) and (16)m-n).

(16) HR nouns with inflectional plurals
$\bar{U}$-c̀̀mว̀
'fathers'
a. còmò 'father'
b. kūmú 'mother'
U-kūmú 'mothers'
c. hàm
'his/her brother'
U-hàm
'his/her brothers'
d. $6 \bar{a} m$
ū-bām
'his/her sister'
'his/her sisters'
e. cājmứn
'father-in-law'
ū-cājmún
'fathers-in-law'
f. kwājmún 'mother-in-law'
u-kwājmún 'mothers-in-law'
g. àbátón 'grandfather'
w-àbátón 'grandfathers'
h. àdíj $\bar{\varepsilon}$
w-àdíje
'(grand)mother'
àsàmá
'sororal nephew/niece'
'sororal nephews/nieces'
w-àsàmá
j àpālā
w-àpālā
'brother-in-law (of male)'
'brothers-in-law'
k. ácòmò 'paternal uncle'
w-ácòmò 'paternal uncles'
1. Gácòmò 'paternal aunt'
Ū-6ácòmò 'paternal aunts'
m. sākám
'his/her maternal uncle'
Ū-sākám
'his/her maternal uncles'
n. Gákūmú
ū-6ákūmú
'his/her maternal aunt'
'his/her maternal aunts'

Even though these nouns form their plural inflectionally, a good number of the singular stems appear to be historically derived forms. For example, the term for 'sister' / $6 \bar{a} m /$ in (16)d) is clearly related to the third feminine pronoun / $\overline{\mathrm{a}} \mathrm{a} /$. Likewise the terms for 'paternal aunt' (16)l) and 'maternal aunt' (16)n) contain the element /6á/, but with the $\mathrm{H}$ tone characteristic of the associative construction (refer to (4)). This element could be analysed synchronically as an associative construction using the pronoun base in the same way as the derived nouns in examples (5), (6) and (7) (e.g. /6ā-(î) còmò/ $\rightarrow$ /6ácòmò/). However, likely it is a phonological reduction of /6ām/ 'sister' used in an associative construction (e.g. /6ām-í còmò/ $\rightarrow$ /6ácòmò/). This would then parallel the element /á/ in /ácòmò/ 'paternal uncle' (16)k), which could be analyzed as a historical reduction of /hàm/ 'brother' in an associative construction (i.e. /hàm-í còmò/ $\rightarrow$ /ácòmò/). ${ }^{9}$ Finally, many of the nouns in this category (16)g-k) appear to begin with the same fossilized prefix /*à-/ that was noted for /àdím $\bar{\varepsilon} /$ 'child' (refer to footnote 7).

The inflectional plural can also be affixed to proper names to form an "associative plural" (Corbett 2000:103, Moravcsik 2017:446-7), not to be confused with the 'associative construction'. The semantics here are "so-and-so and his associates" or "so-and-so and those with him" as illustrated in (17) and (18), with the named individual being the most salient of the group (Moravcsik

\footnotetext{
${ }^{9}$ In an earlier analysis I argued that both /hàm/ and the /á/ of /ácòmò/ were derived from the non-human pronoun base /*hà/. Based on evidence for the source of /hàm/, however, I no longer consider this tenable.
} 
2017:446). Corbett argues from various cross linguistic evidences that this type of plural is actually outside of the formal number system, though it is not uncommon for such a construction to utilize plural morphology as Bilugu Opo does (Corbett 2000:109-10, Moravcsik 2017:446).

$$
\begin{aligned}
& \text { Ū-dćbìd fàā } \\
& \text { PL-David come.PL } \\
& \text { 'David (and those with him) came.' }
\end{aligned}
$$
(18) āgā
gìl ̄-ùtápà
1SG.NOM see PL-Utapa
'I saw Utapa (and his associates).'

2.2.4 Summary of the Top System and Typological Comments. In this section I have shown that the TOP SYSTEM of Bilugu Opo maintains a basic singular plural opposition, and that nominals in this system fall into three major groups divisible both along the animacy hierarchy and by their strategy for number marking. The first category, pronouns, encode number through suppletion (i.e. lexically). The second category, including all HR nouns except kinship terms, encode number through derivational means sourced in the third person pronoun bases (e.g. the prefixes /ò-/ 3SG.M, / $6 \bar{a}-/$ 3SG.F, and /bì-/ 3PL), or through a combination of derivational and lexical means. The third category, roughly corresponding to kinship terms, encodes number inflectionally through the plural prefix / $\overline{\mathrm{U}}-/$, which can also be used to form associative number with proper nouns. A visual overview of the TOP SYSTEM is given in Figure 5, where the dashed line indicates attestation of a particular strategy (given in the first column) with reference to nouns organized along the animacy hierarchy (given in the top row).

Figure 5. Overview of Bilugu Opo number marking strategies in the TOP SYSTEM.

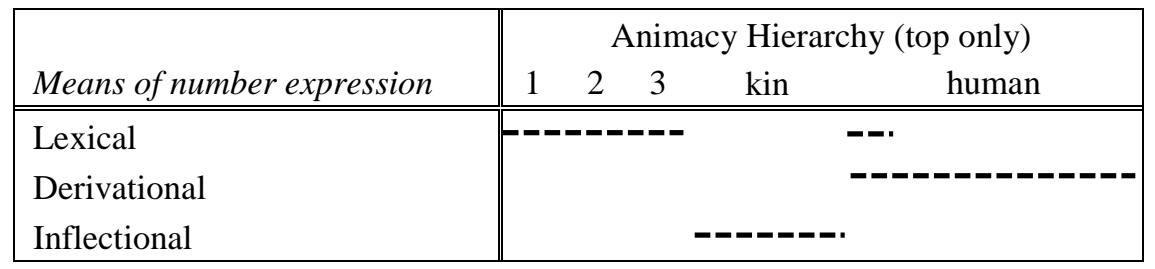

Comparing the TOP SYSTEM to Dimmendaal's description of typical Nilo-Saharan number marking (2000), there are several things to note. First, Bilugu Opo number marking is exclusively prefixing, contrary to Dimmendaal's expectation that Nilo-Saharan systems will be primarily suffixing or a combination of suffixing and prefixing (2000:217). Second, three of the four possible marking patterns (Moravcsik 2017:453) are attested in the TOP SYSTEM: pronouns and most HR plurals mark both singular and plural (both lexically and derivationally), a small set of mostly ethnonyms have an unmarked plural and marked singular, and kinship terms have an unmarked singular with a marked plural. At first glance this looks a lot like Dimmendaal's "tripartite division" between singulative, plural, and "replacive" marking, which he notes is not attested in Koman (2000:216). However, since the gender-number derivational prefixes are undoubtedly derived from the third person pronouns, this correspondence is merely coincidental. The derivational plurals are 
not a true Nilo-Saharan tripartite number marking system. Rather, they are what Dimmendaal calls prefixing nominal derivation, which he says is to be expected in Koman (2000:246-7). Finally, Dimmendaal notes that kinship terms often operate as a "macrocategory" in terms of number marking, using a separate paradigm from other nominals (2000:234), which I have shown to be true in Bilugu Opo. The interesting part of the Bilugu Opo system, however, is that kinship terms not only attest a paradigmatic difference (i.e. an exclusive set of morphology), but also a categorical difference (i.e. inflection versus derivation). This also supports the category KIN as a legitimate division along the animacy hierarchy for distinguishing number systems, which Corbett notes has weak evidence cross-linguistically (2000:59).

\subsection{The Second System: Non-Human Referents}

The SECOND SYSTEM encompasses all non-human referent (NHR) nominals, including animate nouns, inanimate nouns, and their third person referring pronouns. Unlike the HR nominals, the SECOND SYSTEM does not attest a singular plural opposition. Instead it remains unmarked for either singular or plural, even when quantified, inherently expressing GENERAL NUMBER. GENERAL NUMBER as defined by Corbett implies that "the meaning of the noun can be expressed without reference to number [...] it is outside the number system" (2000:10). The fact that GENERAL NUMBER is the only available number value in the SECOND SYSTEM is to be expected typologically (2000:127) and is well attested in other Koman languages. Some Koman linguists use the term TRANSNUMERAL synonymously with GENERAL NUMBER (Killian 2015:62, Otero 2015b:3). The former term, however, is often defined in the context of facultative (optional) number marking, with TRANSNUMERAL being the unmarked option. Further, Acquaviva (2003) defines TRANSNUMERAL as a kind of semantic neutralization of number opposition, so as to include pluralia tantum (e.g. Eng. 'scissors', 'clothes') and cohesive aggregates (e.g. Eng. 'stars'), and other noun classes which would not be considered GENERAL according to Corbett's definition above. Given the situation in Bilugu Opo, where number marking is simply not available for nouns in the SECOND SYSTEM, I prefer Corbett's nomenclature.

In this section I will argue that NHR nominals fundamentally encode GENERAL NUMBER, even though number can be specified secondarily through other constituents. First I outline out my arguments (\$2.3.1), then illustrate how they obtain for various different types of NHR nominals: monomorphemic nouns (§2.3.2), pronouns (\$2.3.3), nouns with derivational prefixes (\$2.3.4). I then note one limited environment where number may be encoded on the noun stem $(\S 2.3 .5)$ and discuss a notable exception to the SECOND SYSTEM, the word /pì/ 'cow' (§2.3.6).

2.3.1 Arguments for NHR nominals encoding general number. There are several proofs that number in the SECOND SYSTEM is general, which I outline in (19) below. I expound (19)a-b) below but reserve (19)c) for $\$ 2.4$.

(19) Arguments for GENERAL NUMBER in the SECOND SYSTEM.

a. When not specified secondarily, number is ambiguous.

b. When number is specified secondarily, NHR nominals do not attest contrasting singular $\sim$ plural forms.

c. Whether or not number is specified secondarily, agreement marking is always $3 \mathrm{NH}$. 
First (19)a), as would be expected for nominals expressing GENERAL NUMBER, unless some other constituent encodes for single or plural, the number value of NHR nominals is ambiguous. Thus, in (20) below, NHR nominals elicited in isolation encode GENERAL NUMBER, both nouns (20)a) and pronouns (20)b).

(20) Nouns and pronouns with ambiguous number value

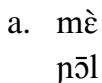
'goat(s)'
'hammer(s)'
b. hén̄̄
nén̄̄
'this/these'
'this/these'

Likewise, in many fully formed sentences the number of NHR nominals can remain ambiguous, regardless of grammatical role. In (21) the S argument /bàj/ 'elephant(s)' encodes GENERAL NUMBER, as does the A argument /tòbò/ 'lion(s)' in (22), and the $\mathrm{O}$ argument /wàc'à/ 'fish' in (23).

(21)

$\begin{array}{ll}\text { bàj } & \text { sísī } \\ \text { elephant } & \text { disappear }\end{array}$

'Elephant(s) disappeared.'

(22) tòbò kàm sūmā

lion find meat

'Lion(s) found meat.'

(23) ùtéñ̄ màl wàc’à

3SG.M:MED catch fish

'He (there) caught (a/some) fish.'

Next (19)b), NHR nouns do not have contrasting singular plural forms even when number is specified by another constituent. We can see this by using a quantifier to force a number interpretation onto an NHR noun and then comparing these with HR nouns in the same context. When modified by /djān/ 'one', the HR noun for 'child' takes the singular form /àdím $\bar{\varepsilon} /$ (24)a), and when modified by /tùsù/ 'three' it takes the suppletive plural form /bìt'í/ (24)b). The NHR noun /mغ̀/ 'goat', however, retains the same form for both singular (25)a) and plural (25)b) interpretations.
a. àdím $\bar{\varepsilon}$ djān
child one

'One child.'

(25)
$\begin{array}{ll}\text { a. } & \text { mè djān } \\ \text { goat } & \text { one }\end{array}$
b. mè tùsù
goat three
'One goat.'
b. bìtrí tùsù
children three

'Three children.

Similarly, the generilzation holds when verbal ajectives with contrasting singular $\sim$ plural stems are applied (see §3), such as /c'í/ 'be black' and its reduplicated form /c'ì c c'í/ 'be black (PL)' (cf. (13)a)). Again, while HR nominals take a plural form (26), NHR nouns remaining unchanged (27). 
$\begin{array}{ll}\text { a. àdím } \bar{\varepsilon}=\text { mú } & \mathrm{c}^{\prime \prime} 1 \\ \text { child }=\text { REL } & \text { be.black }\end{array}$

'A child who is black.'
a. $m \grave{\varepsilon}=$ mú c'í
goat $=$ REL be.black.

'A black goat.'

\author{
b. bìt'î = mú c'ī c'í \\ children=REL REDUP be.black
}

'Children who are black.'

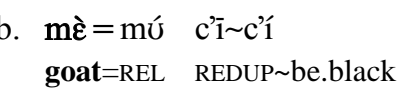

'Black goats.

Proofs (a) and (b) can be summed up by saying that NHR nominals cannot encode number. Number may only be specified by another constituent such as a quantifier or verbal adjective. These same two proofs apply for pronominal agreement markers, as will be seen in \$2.4. Having established that NHR nominals encode GENERAL NUMBER, it should be noted that this does not mean they are never or even rarely specified for number. As seen in examples (25) and (27), this is clearly possible using quantifiers or verbal adjectives. Also, more often than not the number value of a NHR nominal is implicit in the semantics of a verbal predicate due to the great number of verbs which encode PARTICIPANT NUMBER (see §3). My assertion is not that NHR nominals are usually ambiguous in number, but rather that GENERAL NUMBER is basic to them and that singular or plural interpretations are accomplished through other constituents. Thus, number can and often is specified secondarily through another lexeme, but the NHR nominals themselves remain outside the range of singular plural opposition. In the following sections I will show this to be the case for various morphological types of NHR nominals.

2.3.2 Monomorphemic NHR nouns. In my lexical database many NHR nominals are simplex (monomorphemic) nouns. The last subsection amply illustrated GENERAL NUMBER using such nouns: /bàj/ 'elephant(s)' in (21), /tòbò/ 'lion(s)' in (22), /wàc’à/ 'fish' in (23), and /mè/ 'goat(s)' in (25) and (27). Further examples are given in (28) showing that such nouns come from various semantic groups relevant to number marking, including countable animates (28)a), countable inanimates (28)b), prototypically mass nouns (28)c), and abstract nouns (28)d).

(28) NHR monomorphemic nouns

\begin{tabular}{|c|c|c|c|}
\hline \multirow{4}{*}{$\begin{array}{l}\text { a. } \mathrm{k}^{\mathrm{h} a ̀ a ̄ a ̀ ~} \\
\text { diùu } \\
\text { wōjóm } \\
\text { mīlílî̀ }\end{array}$} & 'chicken(s)' & b. cá & 'tree(s)' \\
\hline & 'bird(s)' & kù & 'house(s)' \\
\hline & 'hippo(s)' & wònè & 'foot / feet' \\
\hline & 'whistling $\operatorname{duck}(\mathrm{s})$ ' & tūtūlú & 'musical horn(s)' \\
\hline c. fì & 'water' & d. làm & 'skill(s)' \\
\hline tàm & 'honey' & fàj & 'war(s)' \\
\hline tàr & 'natural light' & cjày & 'behaviour(s)' \\
\hline wárk'é & 'gold' & wāwú & 'season(s)' \\
\hline
\end{tabular}

2.3.3 NHR Pronouns. Like the third person independent HR pronouns given in Table 6 and Table 7, the NHR independent pronouns have base forms which take additional morphology. All NHR 
nouns use one or both of two base forms: /nà/ and /*hà/. ${ }^{10}$ The most common way for these forms to be used as independent pronouns is with the demonstrative enclitics; these are given with their derivations in Table 10.

Table 10. Derivation of Bilugu Opo non-human third person demonstrative pronouns.

\begin{tabular}{|c|c|c|c|}
\hline & PROXIMAL & MEDIAL & DISTAL \\
\hline $3 \mathrm{NH}$ & $\begin{array}{l}\text { nén̄̄ } \\
\text { nà = (î)n̄̄ } \\
\text { 3NH=PROX }\end{array}$ & 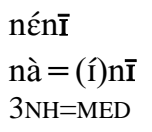 & 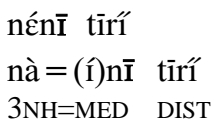 \\
\hline $3 \mathrm{NH}$ & $\begin{array}{l}\text { hén̄̄ } \\
\text { hà =(Î)n̄̄ } \\
\text { 3NH=PROX }\end{array}$ & 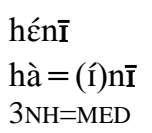 & 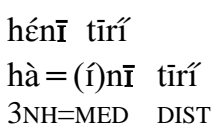 \\
\hline
\end{tabular}

Like all other NHR nominals, these pronouns encode GENERAL NUMBER only; the number value of their referents is ambiguous when not specified by another constituent (or by context) as seen in (29) and (30), and their form does not change regardless of number being specified by another constituent, as seen in (31) (again using the verbal adjective /c'í/ 'be black' to encode number).
a. nén̄̄ tā nà?
3NH:PROX BE what?

'What is this /are these (non-human)?'
a. tā nà -mún
BE 3NH-3PL.POSS

'It is / they are their thing(s)'

\section{b. gí hén̄̄ tā nà?}

CON 3NH:PROX BE what?

'And what is this /are these?'

b. tā hà -mún

BE 3NH-3PL.POSS

'It is /they are their thing(s).'

a. àgā=númá nà=mú čŕ

1SG.NOM=want 3NH=REL be.black

'I want the black one.'

b. àgā=númá $\quad$ nà = mú c'ī c'í

1SG.NOM=want 3NH=REL REDUP be. black

'I want the black ones.'

While the differences between these two pronouns is still not fully understood, it is clearly neither number nor gender. Rather, in cases of contrast /nà/ tends to be used for new information whereas /*hà/ for given information (compare (29)a) with (29)b) which are sequential clauses in the same utterance). Also /nà/ is far more productive than /*hà/, serving exclusively as the non-human pronoun in interrogatives (29) and relative clauses (31).

\footnotetext{
${ }^{10}$ The morpheme /nà/ is not marked with a (*) because it is attested independently as the non-human interrogative pronoun, as in example (29).
} 
2.3.4 NHR nominals with lexicalized, semi-productive, and productive derivational prefixes. A large group of NHR nouns are formed using derivational strategies similar to those described for HR nominals in $\$ 2.2 .2$, but all without reference to number.

A group of mostly animate NHR nouns have what appear to be lexicalizations of the HR derivational prefixes: two words beginning with /ò-/ '3SG.M' given in (32), and many more with / $6 \bar{a}-$ / '3SG.F', a selection of which are given in (33). While historically these may have been productive derivational prefixes, the roots of these words are all fossilized, and thus they are analyzed synchronically as unary lexemes.

(32) NHR nominals with lexicalized /̀̀-/ prefix

$\begin{array}{ll}\text { ùbígí } & \text { 'vervet(s)' } \\ \text { ùtiç } & \text { 'frog(s)' }\end{array}$

(33) NHR nominals with lexicalized / $\bar{b} a \overline{-} /$ prefix

bākūbác' 'patas monkey'

bābìmùs 'centipede(s)'

bājî́rōk' 'little green bee-eater'

bāsílsíl 'lizard'

bākók̄o 'African jacana(s)'

As seen in (34) and (35), these nouns pattern exactly like the NHR monomorphemic lexemes and pronouns, inherently encoding GENERAL NUMBER (a) and maintaining the same form even when a singular (b) or plural (c) interpretations are required by other constituents (unlike HR nouns which would utilize either the plural derivational prefix /bì-/ or the plural inflectional prefix $/ \bar{U}-/$, or a suppletive form).
a. òbígí
vervet
b. ùbígí djān
vervet one
'Vervet(s).'
'One vervet.'
c. òbígí tùsù
vervet three
'Three vervets.'

\section{a. Gābìmùs \\ centipede}
'Centipede(s).'
b. Gābìmùs djān
centipede one
'One centipede.'
c. Gābìmùs tùsù
centipede three
'Three centipedes.'

With few of these nouns the initial / $6 \bar{a}-/$ could possibly be analyzed as a synchronic prefix. For example the word / $6 \bar{a}$ wúlàb $\bar{\varepsilon} \mathrm{s} /$ 'spider' in (36)a) looks like a participant nominalization of the verb /wül// 'scamper' similar to the HR derivations seen in (8), and the word /6āmàr/ 'rainbow' (36)b) appears to be a singular form like those of the HR nouns with an unmarked plural (refer to (14)).

(36) NHR nouns with semi-productive /6ā-/ 'F' prefix

a. bā-wúl-à-b-ēs

F-scamper-SOURCE-OBL-body

'Spider(s).' (lit. one(s) (F) who scamper(s) on the body) 
b. 6ā-màr

F-spirit

'Rainbow(s).' (lit. female spirit, god)

Even if / $6 \bar{a}-/$ is synchronically a prefix, it clearly no longer encodes singular number like the corresponding human prefix / $6 \bar{a}-/$ ' 3 SG.F' since these lexemes pattern exactly like the unary NHR lexemes in (35) with respect to GENERAL NUMBER.

Similarly, a very large group of NHR nominals have either a lexicalized or semi-productive prefix /à-/ 'NA', which I analyze as a phonological reduction of the pronoun base /*hà/ 'NH' (parallel to the HR derivational prefixes which are reductions of their respective pronoun bases). Examples of unary lexemes — with lexicalized prefixes and fossilized roots — are given in (37) below.

(37) NHR nominals with lexicalized /à-/ prefix

$\begin{array}{ll}\text { àhūt } & \text { 'civet cat(s)' } \\ \text { àbáár } & \text { 'heron(s)' } \\ \text { àjìbà } & \text { 'red-billed quelea(s)' } \\ \text { àpùlún } & \text { 'ground hornbill(s)' } \\ \text { àk’̄mák' } & \text { 'millipede(s)' } \\ \text { àdòj } & \text { 'moon(s)' } \\ \text { àtùná } & \text { 'windstorm(s)' } \\ \text { àbùrúk'é } & \text { 'musical horn(s)' }\end{array}$

There are several reasons I consider /à-/ to be semi-productive in some cases. First, a fair number of these lexemes can be synchronically analyzed as participant nominalization deriving the $\mathrm{A}$ or $\mathrm{S}$ participant of a verbal predicate, with a tendency toward agent-like semantics. For example the word /àsácújcàrè/ 'African thrush' is a nominalization of the verb /sá/ 'eat.SG' (38)a), and /àdòncá/ 'woodpecker' of the verb /də̀y/ 'peck' (38)b). Second, some terms can be synchronically analyzed as nominal derivations, such as the word /àwúrí/ 'Rüppel's starling' from /wúrí/ 'red acacia', so named because of the bird's affinity for the tree species. Third, while most novel derivations utilizing /à-/ are not acceptable, they occasionally are, as with the neologism /àdjāns $\bar{\varepsilon} /$ 'rhinoceros', coined by one of my informants (38)d). Fourth, there is evidence that /à-/ is used to adapt borrowed roots into the animate non-human class, as in (38)e).

(38) NHR nouns with semi-productive /à-/ 'NH' prefix

a. à-sá-cúj-càrè

NH-eat-feces.ASC-baboon

'African thrush(es).' (lit. one (NH) who eats baboon feces)

b. à-d’̀n-cá

NH-peck-tree

'Woodpecker(s).' (lit. one (NH) who pecks wood) 
c. à-wúrí

NH-acacia.sp

'Rüppel's starling(s).' (cf. /wúrí/ 'red acacia')

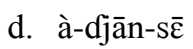

NH-one-tooth

'Rhinoceros(es).' (lit. one (NH) with one tooth)

e. à-jámàl

NH-camel

'Camel(s).' (cf. Arabic /dzamal/ 'camel')

Again, whether /à-/ is lexicalized or semi-productive, the point most relevant to this discussion is that it does not encode either singular or plural number like the corresponding HR derivational prefixes. These lexemes attest GENERAL NUMBER, as illustrated above and in (39) and (40).
a. àhú djān
fish.sp one
b. àhư tùsù
'One fish (sp.).'
fish.sp three
'Three fish (sp.).'

\section{(40) \\ a. àdòycá djān}

'One woodpecker.' $\begin{array}{ll}\text { b. àdð̀ycá } & \text { tùsù } \\ \text { woodpecker } & \text { three }\end{array}$

'Three woodpeckers.'

Finally, there is a large group of NHR nouns productively derived using the pronoun base /nà/ 'NH' or its corresponding derivational prefix /nà-/. Like the HR nouns in $\$ 2.2 .2$ the pronoun base can be put in an associative construction (refer to (4)), as with the examples in (41). Recall that with the HR nominals derived this way, the number value was encoded lexically in the modifying pronoun. So here, as expected, the derivatives follow /nà/ in encoding GENERAL NUMBER.
a. ná-kù
3NH:ASC-house
b. ná-pà
'wickerwork(s)'
3NH:ASC-house
'possession(s), property'

In addition, the derivational prefix /nà-/ can be used for participant nominalization of the $\mathrm{O}$ or $\mathrm{S}$ argument of a verb, with a tendency toward patient-like semantics. Examples of such nominalizations are shown in (42).

(42) HR nouns derived from verb roots
a. cár 'think' nà-cár
'thought(s), idea(s)'
b. tā
nà-tā
'do, work'
'work(s), deed(s)' 

c. $\mathrm{k}^{\mathrm{h}} \mathrm{\jmath}$
'be bad'
nà-k $\mathrm{k}^{\mathrm{h}}$
'evil'
d. sá
'eat.SG'
nà-sá
'meal, food'

Recall in the discussion of HR participant nominalization (\$2.2.2) that certain verbs have contrasting singular and plural stems. In such cases the HR derivational prefix /bì-/ '3PL' attaches to the verbal plural stem. The prefix /nà-/ can likewise derive NHR nominals using verbal plural stems, but such derivations do not simply produce the plural equivalents of nouns derived from singular stems. This is because the plurality being encoded in these forms is not NOMINAL NUMBER, since /nà-/ only encodes GENERAL NUMBER, but rather VERBAL NUMBER inherent to the semantics of the verb (see $\$ 3$ for complete discussion). Consider (43)a) and (43)b), which are repeated from above but expanded to include derivations utilizing the plural stem. While the nominalization of the stem $/ \mathrm{k}^{\mathrm{h}} \mathrm{j} /$ 'be bad' in (43)a) results in a term 'evil', the nominalization of its plural stem results in either 'bad things' or a term for 'garbage' (a kind of mass noun). Similarly in (43)b) the nominalization of the singular stem corresponds to 'food' or 'meal(s)', while that of the plural stem corresponds to 'variety of foods' or 'feast(s)', not simply a grammatical plural. Further examples are given in (43)cd).

(43) HR nouns derived from verb roots

\begin{tabular}{|c|c|c|c|}
\hline a. $\mathrm{k}^{\mathrm{h}} \mathfrak{\jmath}$ & 'be bad' & b. sá & 'eat.SG' \\
\hline $\mathrm{k}^{\mathrm{h}} \overline{\mathrm{\jmath}}-\mathrm{k}^{\mathrm{h}} \mathfrak{\jmath}$ & 'be bad (PL)' & ūsā & 'eat.PL' \\
\hline nà-k $k^{\mathrm{h}}$ & 'evil' & nà-sá & 'meal(s), food' \\
\hline nà- $\mathrm{k}^{\mathrm{h}} \overline{\boldsymbol{\gamma}} \sim \mathrm{k}^{\mathrm{h}} \mathfrak{\jmath}$ & 'bad things, garbage' & nà-ūsā & 'variety of foods, feast(s)' \\
\hline c. k’á & 'sprout (vi.)' & d. sū & 'buy, sell' \\
\hline k'ā $\sim$ '’̄a & 'sprout all over' & sú fú & 'buy, sell (multiple times)' \\
\hline nà-k’á & 'sprout(s)' & nà-sū & 'buying, selling (n.)' \\
\hline nà-k'ā $\sim k^{\prime} \bar{a}$ & 'sprouting things' & nà-sú fú & 'transactions' \\
\hline
\end{tabular}

My point here is that even though it appears that these derived forms are encoding a singular plural contrast, that this is not actually the case. Like all the other types of NHR nominals observed so far, the nominal element of these forms still encodes GENERAL NUMBER, it is only the verbal element that is contributing towards a plural interpretation. Further, the plurality being encoded is not NOMINAL NUMBER, but rather is related to the semantics of the verb (see $\$ 3$ for full discussion).

2.3.5 Secondary number marking in NHR noun stems. Finally, it is important to note that there is one environment where NHR nouns do express NOMINAL NUMBER on the noun-stem. This is when an HR noun acts as an attributive nominal of an NHR noun using the associative construction. This most commonly occurs when a speaker wishes to express the gender or familial role of an animal, as with the examples in (44) (45) and (46). Note, however, that this only applies to suppletive plurals. Thus, even though the HR noun /kūmú/ 'mother' normally takes an inflectional plural, when it becomes the modifier of a NHR noun in (47) (taking the form $/ \mathrm{kōmán} /$ ) it can no longer do so, and the number value of the derived noun is GENERAL. 
(44)

$$
\begin{aligned}
& \text { a. àdímé- }-k^{\mathrm{h}} \mathrm{àa} \\
& \text { child.SG:ASC-chicken }
\end{aligned}
$$

'chick'

(45)

(46)

\author{
b. bìt'̂́-k $\mathrm{k}^{\mathrm{h}} \mathrm{a} a \overline{ }$ \\ child.PL:ASC-chicken \\ 'chicks'
}

b. $\quad \overline{\mathrm{o}} \mathrm{p}^{\mathrm{h}}$ ว- $\mathrm{k}^{\mathrm{h}} \mathrm{àa}$

woman.PL:ASC-chicken

'hens'
b. bàj-Í-k àā
male.PL-ASC-chicken
'roosters'
b. *ū-kūmán-Í-k $\mathrm{k}^{\mathrm{h} a ̀ a}$
*PL-mother.NH-ASC-chicken
*'hens'

2.3.6 An Exception for Cows. There is one noun in Bilugu Opo that breaks the mould of the number system. The word /pì/ 'cow' takes the plural form /pib/ 'cows'. According to Corbett, this is a common exception for languages which attest a human $\sim$ non-human split; domesticated animals such as dogs or cows are often given "honourary human" status for number marking (2000:58). The case of /pì/ 'cow' in Bilugu Opo is interesting, however, because it appears to be highly irregular morphologically. Given its cognates in other Koman languages (see Table 11) the most likely explanation of its form is that of coda-deletion for the formation of the singular, the plural being the original general form. It appears that this is a relatively recent innovation in Bilugu Opo, since the other dialects do not make the same distinction. There was considerable confusion amongst some of my younger informants about which form should be singular, while others noted that the form /pib/ is older and the form /pì/ is an innovation of the current generation.

Table 11. Koman cognates for 'cow'. Data for Komo from Otero (2015a:129), for Uduk from

\begin{tabular}{|c|c|c|c|c|c|c|c|c|c|}
\hline & & \multicolumn{4}{|c|}{ Opo } & Komo & \multicolumn{2}{|c|}{ Uduk } & \multirow[t]{2}{*}{ Gwama } \\
\hline & & Bilugu & Modin & Pame & Dana & Ethiopian & Chali & Yabus & \\
\hline \multirow{2}{*}{ 'cow' } & SG & pì & \multirow{2}{*}{ pì } & \multirow{2}{*}{ pì } & \multirow{2}{*}{ pì } & à = bìb & \multirow{2}{*}{ bìp ${ }^{\mathrm{h}}$} & \multirow{2}{*}{ bì? } & \multirow{2}{*}{ Ímí } \\
\hline & PL & pìb & & & & gù = bìb & & & \\
\hline
\end{tabular}
Killian (2015:105, p.c.), and for Gwama from Justin Goldberg (p.c.).

2.3.7 Summary of the Second System. In this section I have shown that NHR nominals utilize a SECOND SYSTEM of number expression which fundamentally encodes GENERAL NUMBER. Singular or plural NOMINAL NUMBER may be specified by other constituents, such as quantifiers, verbal adjectives, or HR nominals with suppletive plurals functioning as attributive nominals, but it can never be specified on the nominal itself. This is the case even when an NHR nominal is derived using the participant nominalizing derivational prefixes. Unlike those of the TOP SYSTEM, such 
prefixes in the SECOND SYSTEM are mostly lexicalized, forming unary lexemes with fossilized roots. But even those which are productive like /nà-/ 'NH', or semi-productive like /à-/ 'NH' and possibly / $\bar{b} \bar{a}-/$ 'F', do not encode number as they do for HR nouns. Rather, they derive nominals loosely based on agency or grammatical role, with /à-/ and / $\bar{b} \bar{a}-/$ being semi-productive for more agent-like nominalizations and /nà-/ productive for patient-like nominalizations. In cases where the productive /nà-/ derives NHR nominals from verbal plural stems, the result is not plural NOMINAL NUMBER but rather a plurality related to the semantics of the verb itself. ${ }^{11}$

\subsection{Nominal Number Agreement on the Verb Stem}

In this section I will examine how NOMINAL NUMBER is marked on the verb stem through pronominal agreement markers (a.k.a. anaphoric clitics). The pattern here is quite simple and makes the split between the top and second systems even more obvious: pronominal agreement markers always agree in number and natural gender with the HR nominal they anaphorically reference, but when referencing NHR nominals take only the non-human form.

The pronominal agreement markers for Bilugu Opo are given in Table 12, including nominative, accusative, and benefactive forms, and their corresponding possessive suffixes. Note that the first person singular and plural, and the second person plural agreement markers are the same as the independent pronouns given in Table 6. These morphemes live somewhere on the edge between being free words and clitics, so in some cases I gloss them as clitics (e.g. most examples in this section), and in other cases as free words (refer to examples (1) and (2)).

Table 12. Bilugu Opo pronominal agreement markers. ${ }^{12}$

\begin{tabular}{|c|c|c|c|c|}
\hline & NoM & ACC & BEN & POSS \\
\hline $1 \mathrm{SG}$ & $\bar{a} g \bar{a}$ & $=\bar{a} g \bar{a}$ & gágá & -(Î)má \\
\hline $2 \mathrm{SG}$ & $\overline{1}=$ & $=\bar{a} j$ & gáj & míní \\
\hline 3SG.M & $\overline{\mathrm{a}} \mathrm{r}=$ & $=\bar{a} r$ & gár & $-(\hat{I}) r$ \\
\hline 3SG.F & $\bar{a} b=$ & $=\bar{a} b$ & gáb & $-(\hat{I}) b$ \\
\hline $3 \mathrm{NH}$ & $\overline{\mathrm{a}} \mathrm{n}=$ & $=\bar{a} n$ & gán & $-(\hat{I}) n$ \\
\hline
\end{tabular}

${ }^{11}$ My analysis of the Bilugu Opo SECOND SYSTEM differs significantly from that of Lemi, who claims that there is a prefix /buwaa-/ which can be used to pluralize non-human nouns (2010:14). This is likely the quantifier /búá/ 'many, much', the nature of which becomes clear with some testing: it is not obligatory for specifying a plural referent, it can be added to already plural referents to intensify number (e.g. /búá ūcòmò/ 'many PL-fathers'), and it is ungrammatical when mixed certain other quantifiers (e.g. */búá tòbò tùsù/ 'many three lions?').

${ }^{12}$ Note that for both the nominative and accusative forms there is often tonal assimilation and vowel coalescence with surrounding constituents. I show the effects of a process when I consider it phonemic (e.g. $/ \bar{a} \mathrm{a} \bar{a}=\mathrm{à} /$ '1SG.NOM=IPFV $\rightarrow$ /àgà/ '1SG.NOM:IPFV'), but not when I consider it phonetic (e.g. /kàrà = ān/ 'hear=3NH.ACC' $\rightarrow$ [kàràn]). In line with this, note that benefactives in this table are derived from the proclitic /gá=/ 'BEN' plus the accusative enclitic. In most forms the vowel of /gá=/ will elide and spread its $\mathrm{H}$ tone to the latter, the effects of which I show (e.g. /gá = ūn/ 'BEN=3PL' $\rightarrow$ /gún/ 'BEN:3PL'). The 1PL forms do not cause the vowel of /gá $=/$ to elide, being consonant initial, but do receive $\mathrm{H}$ tone spread (e.g. /gá = mànà/ $\rightarrow$ /gá= máná/ 'BEN=1PL.EXCL'). 


\begin{tabular}{|c|c|c|c|c|}
\hline 1PL.INCL & mìnà & = mìnà & gá = mínā & míná \\
\hline 1PL.EXCL & mànà & $=$ mànà & gá = máná & máná \\
\hline $2 \mathrm{PL}$ & $\bar{u} m \bar{a}$ & $=\bar{u} m \bar{a}$ & gứmá & mwá \\
\hline 3PL & $\bar{u} n=$ & $=\bar{u} n$ & gứn & mún \\
\hline
\end{tabular}

Looking first at the TOP SYSTEM, all HR nominals take agreement markers corresponding with their person (i.e. first, second, third) real-world number (i.e. singular or plural) and natural sex (i.e. male or female, except for the rare case of non-human for unisex agreement). Thus, in the third person if a referent is singular the corresponding agreement marker will be either masculine or feminine depending on its natural gender, or if a referent is plural it will be plural. This can be seen in (48) using the unisex word /àdím $\bar{\varepsilon} /$ 'child'. When the speaker is referencing a male child pronominal agreement markers are singular masculine (48)a), when referencing a female child agreement markers are singular feminine (48)b), and when the referent is changed to the plural /bìt'́l' 'children' agreement is also plural (48)c). ${ }^{13}$ In both cases gender could be specified by adding /ùkày/ 'man' and /bāphà/ 'woman', or /bày/ 'men' and /̄̄p $\mathrm{p}^{\mathrm{h}} \overline{\mathrm{g}} /$ 'women' as attributive nominals modifying /àdím $\bar{\varepsilon} /$ or /bìt'í/ respectively, but this would have no effect on agreement. Note that in these examples, and most that will follow in this section, the verb in the first clause does not contain a pronominal agreement marker because the subject is already specified by an overt noun phrase. Agreement markers found in the second clause anaphorically reference this noun phrase. When verbs are arranged serially (as with 'eat food, drink water' in (48)) usually only the first verb takes an agreement marker. Also note that the variation between singular and plural verb stems found in these examples will be explained fully in $\S 3$; it does not count as agreement with NOMINAL NUMBER, but rather PARTICIPANT NUMBER.

$$
\begin{aligned}
& \text { a. àdím } \bar{\varepsilon} \text { fū. àbì k'ōrón } \bar{a} \mathbf{a}=\text { sá mà, } \mathrm{p}^{\mathrm{h}} \mathbf{i} \quad \text { fì, } \\
& \text { child come.SG afterwards 3sG.M.NOM=eat.SG food drink.SG water } \\
& \bar{a} \mathbf{r}=\text { jà. } \\
& \text { 3SG.M.NOM=go.SG }
\end{aligned}
$$

'A child came. Afterwards he ate food, drank water, and left.'

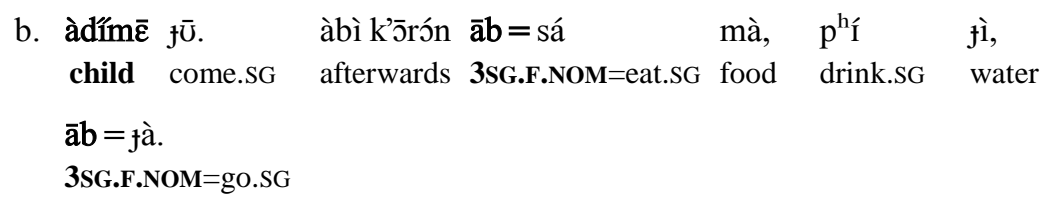

'A child came. Afterwards she ate food, drank water, and left.'

\footnotetext{
${ }^{13}$ Note that in these example I have glossed the phrase /àbì k'ōrón/ as 'afterwards' to better reflect the semantics, but it is actually constructed from /à-bì/ 'SOURCE-OBL' and /k'ōrón/ 'back:3NH.POSs' which could be translated more literally as 'from its back'.
} 


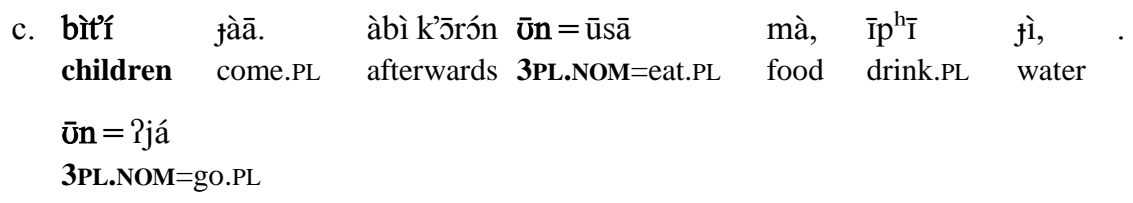

'Children came. Afterwards they ate food, drank water, and left.'

Use of non-human agreement marker /ān/ for singular unisex agreement with human referents is very rare, but is nevertheless attested. There are instances, for example, where it is used to refer to a HR such as a very small child, as in (49). ${ }^{14}$ This, along with the lexicalized /*à-/ seen on HR kinship terms, is evidence that the non-human paradigm, including the pronoun /*hà/ and the derivational prefix /à-/, possibly comes from a historical neuter.

$$
\begin{array}{llll}
\text { àdím } \bar{\varepsilon} & \text { mú }=\bar{u} n=\mathrm{t}^{\mathrm{h}} \tilde{u}, & \mathrm{ku} m u ́ & \mathrm{k} \text { t̀ }=\overline{\mathbf{a}} \mathbf{n} \\
\text { child } & \text { REL=3PL.NOM=give.birth } & \text { mother.3POSS } & \text { hold=3sG.N.ACC }
\end{array}
$$

'The child that was born, its mother held it.'

Looking at the SECOND SYSTEM, for NHR nominals there is only one option for pronominal agreement markers: the non-human /ān =/ '3NH.NOM', / =ān/ '3NH.ACC', /gán/ '3NH.BEN' (refer to Table 12 above). While /ān/ encodes singular number in the rare cases when it indexes a HR nominal, it indexes GENERAL NUMBER when used with NHR nominals. Thus in (50), since the number value of /bàj/ 'elephant(s)' is not specified by another constituent it remains ambiguous (general), as does its agreement marker in the following clause.

$$
\begin{aligned}
& \text { (50) bàj bēr-ú. àpíjén̄̄ ān= sî́sī. } \\
& \text { elephant arrive-DD1 now 3NH.NOM=disappear }
\end{aligned}
$$

'Elephant(s) arrived here. Now it/they disappeared.'

As per my argument in (19)c) for GENERAL NUMBER in the SECOND SYSTEM, even when other elements in the clause force a number interpretation of a NHR, the pronominal agreement markers remain the same. Thus in (51) when a quantifier is added to the sentence from (50) the referent's number is now specified, but the pronominal agreement marker does not change form whether this is singular Error! Reference source not found.a) or plural (51)b).
a. bàj
djān $\quad$ bērr-ú. àpíjén̄̄
$\bar{a} \mathrm{n}=$ sî́sī.
elephant one arrive-DD1 now
3NH.NOM=disappear

'One elephant arrived here. Now it disappeared.'
b. bàj tùsù $\quad 6 \bar{\varepsilon} r-u ́ . \quad$ àpíjénō
$\bar{a} n=$ sî́si.
elephant three arrive-DD1 now
3NH.NOM=disappear

'Three elephants arrived here. Now they disappeared.'

\footnotetext{
${ }^{14}$ Note that the 3PL clitic on the relative clause in this example is a means of expressing passiveness, as is reflected in the free translation. Also note that /kūmó/ 'mother.3POss' is inalienably possessed.
} 
The same applies to NHR nominals which are formed with lexicalized or semi-productive derivational prefixes. Regardless of whether the noun attests the non-human /à-/, feminine / $\bar{b} \bar{a}-/$, or masculine /ù-/, the agreement marker is always /ān/ '3NH'. Thus in (52) below the word /bāgúlúl/ 'yellow-billed kite' takes the general non-human agreement, despite having a lexicalized feminine prefix / $6 \bar{a}-/$. Again, this is true even when number is specified by other constituents, as is the case

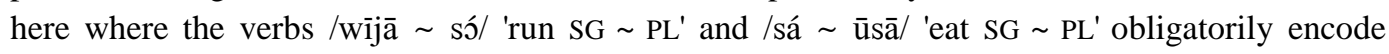
PARTICIPANT NUMBER (see $\S 3$ ).
a. Gāgớlứ wìj-ú. kite run.SG-DD1
àbì k’ōrón $\bar{a} n=p^{\mathrm{h}} \bar{\jmath}$
$\mathrm{k}^{\mathrm{h}} \mathrm{àa} \quad$ sá $=\bar{a} \mathrm{n}$
$\overline{a ̄ n}=$ wìjā.
3NH.NOM=run.SG
afterwards 3NH.NOM=catch
chicken
eat. $. \mathbf{S G}=3 \mathrm{NH} . \mathrm{ACC}$

'A kite came. Afterwards it caught chicken(s), ate it/them, and left.'
b. Gāgứlưl só-wú. àbì k’ōrón $\bar{a} n=\mathrm{p}^{\mathrm{h}} \overline{\mathrm{o}} \quad \mathrm{k}^{\mathrm{h}}$ àā $\quad \bar{u} \mathrm{a} \bar{a}=\bar{a} n$
kite run.PL-DD1 afterwards $3 \mathrm{NH} . \mathrm{NOM}=\mathrm{catch}$ chicken eat.PL=3NH.ACC
$\bar{a} \mathbf{n}=\mathbf{s}$.

3NH.NOM=run.PL

'Kites came. Afterwards they caught chicken(s), ate it/them, and left.'

Finally, even when an NHR is specified for gender and number through an attributive nominal (refer to §2.3.5), the pronominal agreement is still general non-human. Thus in (53) number and gender are specified by the HR nouns /ùk'ày/ 'man' (53)a) and /bàf/ 'men' (53)b) modifying the general NHR /fùwà/ 'large feline(s)', but in both cases the pronominal agreement markers referring back to them is the general non-human $/ \bar{a} n=/$. If these HR attributive nominals were removed, the NHR's number would again be ambiguous (general). This same pattern obtains for NHR nominals modified by feminine HR attributive nominals (e.g. / Gāphá-fùwà/ 'female feline').
a. ̀̀k’ày-Í-jùwà
6̄êr-ú. $\quad$ àbì k'ōrón $\quad \bar{a} n=p^{\mathrm{h}} \bar{\jmath}$
$\mathrm{k}^{\mathrm{h}} \mathrm{àa}$,
$\overline{\mathbf{a}} \mathbf{n}=$ sísī. man-ASC-feline
arrive-DD1 afterwards 3NH.NOM=catch
chicken
3NH.NOM=disappear

'A male feline arrive here. Afterwards it caught chicken(s), and disappeared.'
b. bày-Í-yùwà men-ASC-feline

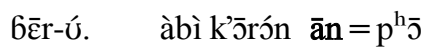
$\mathrm{k}^{\mathrm{h} a ̀ a ̄}$,
$\bar{a} \mathrm{n}=$ sísí.
arrive-DD1 afterwards 3NH.NOM=catch
chicken 3NH.NOM=disappear

'Male felines arrived. Afterwards they caught chicken(s), and disappeared.'

It is clear from the examination of pronominal agreement markers and their function in agreeing with NOMINAL NUMBER that Opo indeed operates with two number systems: the TOP SYSTEM applying to HR nominals which obligatorily encodes a singular $\sim$ plural opposition, and the SECOND SYSTEM applying to NHR nominals which encodes GENERAL NUMBER (only specifying number through other constituents). 


\section{Verbal Number in Bilugu Opo}

Having laid the foundation of number in the noun system of Bilugu Opo I will now describe number in the verb system, which I claim is VERBAL NUMBER (Corbett 2000) or PLURACTIONALITY (Newman 1990). In §3.1 I introduce my terminology and give an overview of the phenomenon in Bilugu Opo. In the following sections I describe two groups of verbs differentiated by how they derive the plural stem and the resulting semantics. First, I describe a large group of verbs which encode VERBAL NUMBER through three morpho-phonemic strategies - tonal modification, vowel gemination, and reduplication - showing that the semantics are relatively unpredictable, depending heavily on lexical information and context to determine whether they affect PARTICIPANT NUMBER or EVENT NUMBER or both (\$3.2). Next I describe a small group of high-frequency verbs which predictably encode PARTICIPANT NUMBER via two lexical strategies: suppletion or stem alternation (\$3.3). Finally, I outline my arguments as to why the phenomena of both the morpho-phonemic and lexical verbal plurals do in fact constitute VERBAL NUMBER or PLURACTIONALITY as opposed to mere agreement with NOMINAL NUMBER (\$3.4).

\subsection{Defining Verbal Number}

Corbett defines VERBAL NUMBER as "number related to the semantics of the verb, and not merely marked on it" (Corbett 2000:243). This term corresponds to Newman's PLURACTIONAL or PLURACTIONALITY $(1990,2012)$, which he defines as "derived plural verb stems denoting semantic plurality" in contrast with "inflected plural verb forms required by a conjugational concord system" (2012:188). In order to more finely categorize the semantics of VERBAL NUMBER / PLURACTIONALITY, I will follow Corbett in using the term PARTICIPANT NUMBER to refer to VERBAL NUMBER which affects the semantics of nominal arguments of a verb (2000:246), and the term EVENT NUMBER to refer to VERBAL NUMBER which yields a plurality of events such as iterative, serial, or repeated action (2000:248). I will continue to use VERBAL NUMBER and PLURACTIONALITY as equivalent cover terms for both PARTICIPANT NUMBER and EVENT NUMBER.

In Bilugu Opo, in addition to the number-gender concord system observed in the pronominal clitics (\$2.4), there is an entirely different system of number expression which occurs in the verb system via modification of the root. This modification fundamentally affects the semantic plurality of the verb rather than simply indexing the number value of the verb's arguments. Furthermore, both the form of modification and the semantic effects in Bilugu Opo are varied and relatively unpredictable, depending heavily on lexical and contextual information. This aligns exactly with the kind of morphologically and semantically diverse verbal plural derivation which Newman considers prototypical of PLURACTIONAL (2012:187-88).

VERBAL NUMBER is actually common in Koman, being attested in Sudanese Komo (Burns 1947), Ethiopian Komo (Otero 2015a:126), Chali Uduk (Stevenson 1942, Killian 2015:181), and Gwama (Hellenthal 2017). In Bilugu Opo, however, the system appears to be much more extensive than in other Koman languages. Firstly, verbs attest all possible types of VERBAL NUMBER predicted by Corbett (2000), both EVENT NUMBER and PARTICIPANT NUMBER affecting all possible arguments of the verb - single participants (S), agent arguments (A), and patient arguments (O). Secondly, as mentioned, the semantics are wide ranging, including iterative, repetitive, and successive effects on the verbal event, as well as multiplicity or variety of verbal arguments. Thirdly, verbs attest multiple 
different morpho-phonemic and lexical strategies for encoding this VERBAL NUMBER: tonal modification, vowel gemination, reduplication, suppletion, and stem alternation. ${ }^{15}$

The basic patterns of this phenomenon in Bilugu Opo are illustrated in (54) through (57) below. Observe the modification of the verb stem between (a) and (b) and the corresponding change in semantics. In (54) the verb /wōrī/ 'flash' undergoes tonal modification and the multiplicity of events is affected; in Error! Reference source not found. the verb /6út'/ 'be weak' undergoes partial reduplication and the multiplicity of S participants is affected; in (56) the verb /sá/ 'eat' takes an alternative stem and the number of A arguments is affected; and in Error! Reference source not found. the stem /dír/ 'gather' reduplicates and the variety of $\mathrm{O}$ arguments is affected.

$$
\begin{aligned}
& \text { a. } \quad \bar{a} n=\text { wōrī } \\
& \text { 3NH.NOM=flash.SG }
\end{aligned}
$$

'It flashed (lightning).'
a. ān= bứt
3 NH.NOM=be.weak
'It is weak.'
a. sá mà!
eat.SG food
'(You SG) eat food!'
a. $\bar{a} r=$ dír $=$ àn
3SG.M.NOM=gather $=3 \mathrm{NH} . \mathrm{ACC}$

'He gathered (the) things.' b. ān= wórí

3NH.NOM=flash.PL

'There were many flashes of lightning.'

b. $\bar{a} n=6 \bar{u} \sim b u ́ t$

3 NH.NOM=REDUP $\sim$ be.weak

'They (objects) are weak'

b. $\bar{a} r=d \bar{i} \sim \operatorname{di} r=\bar{a} n$

3 SG.M.NOM $=$ REDUP $\sim$ gather $=3 \mathrm{NH} . \mathrm{ACC}$

'He gathered (the) various things.'

It should be noted that not all verbs in Bilugu Opo can encode VERBAL NUMBER. In fact over half of all verb roots in my lexicon do not attest any kind of plural stem (see (96) in \$3.4). The remainder, those verbs which can encode VERBAL NUMBER, may be organized into two slightly overlapping groups according how they derive the verbal stem and the resulting semantics. First, there is a large group of verbs which encode EVENT NUMBER or PARTICIPANT NUMBER (with specific semantics lexically and contextually determined) by means of tonal modification, vowel gemination, and reduplication. I will refer to these as the morpho-phonemic verbal plurals. Second, there is a small group of high-frequency verbs which predictably encode PARTICIPANT NUMBER through suppletion or stem alternation. I will refer to these as lexical verbal plurals. In the following two sections I discuss these two groups in detail.

\footnotetext{
${ }^{15}$ This description again differs significantly from that of Lemi, who claims some verbs as having distinct singular and plural stems differentiated by $\mathrm{L}$ tone and $\mathrm{H}$ tone respectively, or by a prefix /u-/ (2010:21). As is demonstrated in the present paper, however, the form and semantics of VERBAL NUMBER in Opo is much more complex than this.
} 


\subsection{Morpho-Phonemic Verbal Plurals}

Just under half of all verbs in my lexical database encode VERBAL NUMBER by deriving a plural stem via three different morpho-phonemic strategies. Specifically, these strategies are tone modification - meaning verbs encode VERBAL NUMBER through changing or replacing the tonal pattern of the root / singular stem - vowel gemination - meaning verbs encode VERBAL NUMBER through gemination of the vowel in the first syllable - and reduplication - meaning verbs encode VERBAL NUMBER through partial reduplication. ${ }^{16}$ Interestingly, provided how varied the forms and semantics can be, most verbs will employ only one of these strategies (see §3.2.4 for an example of multiple strategies employed on the same verb). In the following subsections I give examples of the form and semantics attested for each of these strategies.

3.2.1 Tone Modification. The most common strategy for deriving a plural stem is through modification of a verb's tonal pattern. ${ }^{17}$ The form of these patterns is for the most part unpredictable; I therefore broadly categorize them into register raising and register lowering patterns. A chart of the patterns observed thus far is given in Table 13. Token counts in this chart are based on the number of verbs in my lexical database which attest different singular and plural stems through tone modification only.

\footnotetext{
${ }^{16}$ It should be noted that the latter two processes often also include modification of the root tone pattern.

${ }^{17}$ Note that I follow Snider in treating level tone patterns across multiple syllables as a single tone and contour tones on a single syllable as a sequence of two tones (2017:14-15). Thus, for example, both the verbs $/ \mathrm{k}^{\prime} \overline{\mathrm{s}} /$ ' 'be absent' and $/ \mathrm{k}^{\mathrm{h}} \overline{\mathrm{a}} \mathrm{a} / \mathrm{a} / \mathrm{be}$ red $\mathrm{SG}^{\prime}$ would be said to have a M pattern, not M and MM. Note also that in cases of bound roots, I do not count the tone of the derivational morphology as part of the root melody. Thus with /îsá îsá/ 'approach DD2' and /īsú îsú/ 'approach DD1', where /*îs ̂́s/ is unattested, I count both as a single occurrence of $\mathrm{M} \rightarrow \mathrm{X}$ tonal modification.
} 
Table 13. Tonal modification patterns for singular and plural stems.

\begin{tabular}{|c||ccc|}
\hline & Singular Pattern & Plural Pattern & Tokens in Lexicon \\
\hline \hline \multirow{5}{*}{ Register raising } & M & X & 10 \\
patterns & M & XM & 1 \\
& M & H & 13 \\
& MH & H & 1 \\
& LH & X & 1 \\
& L & X & 1 \\
& L & H & 2 \\
\hline \multirow{5}{*}{ Register lowering } & L & X & 5 \\
patterns & X & MH & 1 \\
& X & M & 2 \\
& H & MH & 1 \\
& MH & MH & 1 \\
& MH & M & 4 \\
& & LM & 1 \\
\hline
\end{tabular}

Besides register raising patterns being more common, and within that a disproportionate number of $\mathrm{L}$ or $\mathrm{M}$ roots changing to $\mathrm{H}$ or $\mathrm{X}$ in the plural stem, $\mathrm{I}$ have not yet been able to discern a rule for tonally deriving a plural stem. ${ }^{18}$ Example (58) shows a register raising pattern $(\mathrm{M} \rightarrow \mathrm{H})$, whereas example Error! Reference source not found. shows a verb with a register lowering pattern $(X \rightarrow L)$.

(58) Tone modification affecting PARTICIPANT NUMBER of $\mathrm{S}$
a. $\overline{\mathrm{a}} \mathrm{n}=\mathbf{k}^{\mathrm{h}} \overline{\mathrm{a}} \mathrm{p} \overline{\mathbf{a}}$
3 NH.NOM=be.red.sG
b. $\bar{a} n=\mathbf{k}^{\mathrm{h}}$ ápá
3NH.NOM=be.red.PL
'It is red.'
'They (non-human) are red.'

(59) Tone modification affecting PARTICIPANT NUMBER of A
a. $\bar{a} r=$ úp
sह̄mà
b. $\bar{u} n=$ ùp
sēmà
3SG.M.NOM=wash.sG clothes
3PL.NOM=wash.PL clothes
'He washed clothes.'
'They washed clothes.'

The semantic effects of this tonal modification are varied, depending heavily on both lexical information and the context. In the two examples just given, the plural stem rather straightforwardly indicates the PARTICIPANT NUMBER of the $\mathrm{S}$ and A (nominative) arguments, respectively. The same is shown for the $\mathrm{O}$ argument in (60) below.

\footnotetext{
${ }^{18}$ One phonological generalization I have observed is that [+ATR] vowels tend to become /X/ when raised and $/ \mathrm{L} /$ when lowered, whereas [-ATR] vowels tend to become $/ \mathrm{H} /$ when raised and $/ \mathrm{M} /$ when lowered.
} 
(60) Tone modification affecting PARTICIPANT NUMBER of $\mathrm{O}$
a. $\bar{a} r=d \bar{y} t$
mè
3SG.F.NOM=leash.SG goat
b. $\bar{a} r=d o ́ t$
mè
3SG.F.NOM=leash.PL goat
'He leashed a goat.'
'He leashed goats.'

In (61) below, repeated from (54) above, tonal modification affects EVENT NUMBER, yielding a kind of iterative aspect.

(61) Tone modification affecting EVENT NUMBER
a. $\bar{a} n=w \overline{o r} \overline{\mathbf{r}}$
3NH.NOM=flash.SG
b. ān= wórí
3NH.NOM=flash.PL
'It flashed (lightning).'
'There were many flashes of lightning.'

In (62) below the semantic effect is a blend of PARTICIPANT NUMBER of the $\mathrm{O}$ argument and EVENT NUMBER. Here the scene is a woman grinding grain, which is typically treated as a mass noun cross-linguistically (compared to a typical count noun like /mغ̀/ 'goat' in example (60)). ${ }^{19}$ When the plural verb stem is applied in (62)b), it is not the multiplicity of grains affected, but rather the variety or number of kinds of grains. The sense is that the woman is grinding multiple times (EVENT NUMBER) and consequently multiple kinds of grain (PARTICIPANT NUMBER), since even a long day of grinding only one kind of grain would likely be considered a single event.

(62) Tone modification affecting PARTICIPANT NUMBER of O / EVENT NUMBER
a. $\bar{a} b=$ fùk’à $=\bar{a} n$
3sG.F.NOM=grind.sG $=3 \mathrm{NH} . \mathrm{ACC}$
b. $\bar{a} b=$ fúk'ä $=\bar{a} n$
3SG.F.NOM=grind.PL=3NH.ACC
'She ground it (grain).'
'She ground it (various kinds of grain).'

In some cases, examples which appear at first to affect PARTICIPANT NUMBER of the A argument can yield this integrated PARTICIPANT O / EVENT NUMBER effect when the plural stem is used with a singular A argument. For example, in Error! Reference source not found. the verb /sūtāa/ 'scoop' is used in the context of people scooping stew from a pot with a piece of /mápj̀/ 'traditional bread'. The difference between (a) and (b) at first appears to be only the number value of the subject. However, when the plural stem is employed with a singular subject, as in Error! Reference source not found.c), it yields a variety of $O$ arguments (various kinds of stew being scooped), or distributive aspect (one kind of stew from various pots).

\footnotetext{
${ }^{19}$ Since all NHR nominals in Bilugu Opo only encode GENERAL NUMBER, along with their bound pronominal agreement markers, the difference between count and mass nouns is morphologically irrelevant in terms of NOMINAL NUMBER. As shown here, however, the difference is relevant for the semantic effect of VERBAL NUMBER.
} 
(63) Tone modification affecting PARTICIPANT NUMBER of A and O / EVENT NUMBER

a. $\bar{a} \mathbf{r}=s \bar{u} t \bar{a}=\bar{a} n$

3sG.M.NOM=sCoop.SG=3NH.ACC

'He scooped it (stew)' b. $\bar{u} n=s u ̛ ́ t \bar{a}=\bar{a} n$

3SG.M.NOM=SCOOp.PL $=3 \mathrm{NH} . \mathrm{ACC}$

'They scooped it (stew)'

c. $\bar{a} r=s u ́ t \bar{a}=\bar{a} n$

3sG.M.NOM=sCoOp.PL=3NH.ACC

'He scooped it (various kinds of stew / multiple pots).'

Error! Reference source not found.c) compels us to analyze the semantics of Error! Reference source not found.a) and Error! Reference source not found.b) as more event oriented. The action of a single person scooping a single type of stew is considered a singular event and so employs the singular stem Error! Reference source not found.a), whereas the action of multiple individuals scooping stew (possibly of various types or from multiple pots) is considered multiple simultaneous instances of an event and thus employs the plural stem.

In other cases, the employment of the plural stem will vary depending on the sense of the verb. Consider the verb /yùgà/ 'call' in (64) and (65), which takes the sense 'to name' and 'to beckon' respectively. In both examples the contrast between (a) and (b) is that of a singular to a plural object. In (64)a) the act of naming a single individual takes the singular stem. In (64)b) the act of naming two individuals employs the plural stem, yielding a distributive aspect (EVENT NUMBER) over multiple objects (PARTICIPANT NUMBER). ${ }^{20}$ In (65), however, the acts of beckoning a single individual (65)a) or multiple individuals (65)b) are both interpreted as singular events, and thus the singular stem is used.
a. ̀̀nà- fùgà
jùgér
gá c’álá
3PL.NOM:IPFV-call.SG
name.SG:3M.POSS
COMP Chala

'He is called Chala.' (lit. they call his name Chala)
b. ùnà- fúgä
fưgá -mứn
gá bākáj gō
3PL.NOM:IPFV-call.PL
name.PL-3PL.POSS
COMP

'Their names are Bakay and Batuk.' (lit. they call their names Bakay and Batuk)
a. $\quad \bar{u}=$ jùgà
c’álá
3PL.NOM=call.SG Chala
'They beckoned Chala.'
a. ūn= jùgà bākáj gū bātùk
3PL.NOM=call.sG Bakay COM Batuk

'They beckoned Bakay and Batuk.'

\footnotetext{
${ }^{20}$ Note in example (64) that the singular and plural stems /yùgà $\sim$ fúgá/ are zero-derived as the noun for 'name names'. Note also that the use of the plural nominative subject /ūn=/ can be interpreted either as a plural agent or as a kind of passive. This is a common strategy for passives in Koman.
} 
From these various examples it is clear that tonal plural stems are not a concord system triggered by the NOMINAL NUMBER value of one of the verb's arguments. Rather it is derived VERBAL NUMBER, the exact semantics of which are determined partially by the lexical semantics of the verb and partially by the context. One final example emphasizes this. In (66) the use of the plural stem /k'̄ss̄/ 'kill PL' as an imperative is ambiguous outside of context. If the imperative is directed towards a single addressee, the interpretation is distributive (i.e. killing multiple things in multiple events). If the imperative is directed toward multiple addressees, the interpretation could either be of multiple A arguments (e.g. simply multiple people engaged in killing) or multiple $\mathrm{O}$ arguments (e.g. killing multiple things as simultaneous events).

k'ōs̄̄ $=\bar{a} n !$

kill.PL $=3 \mathrm{NH} . \mathrm{ACC}$

'(You SG) kill them (non-human)! / (You PL) kill them (non-human)!'

3.2.2 Vowel Gemination. A less common strategy for deriving a plural stem is through lengthening the vowel of the first syllable. This lengthening may or may not be accompanied by tonal modification, and is attested with both polysyllabic Error! Reference source not found. and monosyllabic roots Error! Reference source not found.. Note again that I show length with double letters /aa/ instead of the IPA length marker /a:/.

(67) Vowel gemination affecting EVENT NUMBER

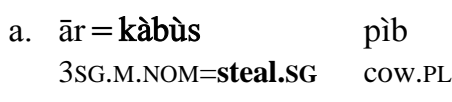
b. $\bar{a} r=$ kàābús pìb
3PL.NOM=steal.PL cow.PL
'He stole cows.'
'He stole cows repeatedly.'

(68) Vowel gemination affecting PARTICIPANT NUMBER of S
a. ùténī Mừj
3SG.M:MED die.SG
$\begin{array}{ll}\text { b. bìjén̄ } & \text { Mưòj } \\ \text { 3PL:MED } & \text { die.PL }\end{array}$
'That one (M) / he died.'
'Those ones / they died.'

Like tonal modification, the semantics of vowel gemination depends on the lexical semantics of the verb and the context, possibly affecting PARTICIPANT NUMBER of any argument or EVENT NUMBER. In (67) above, where both (a) and (b) have singular A and plural O arguments, the stem change in /kàbùs/ 'steal' has the effect of repetitive or habitual aspect (EVENT NUMBER).

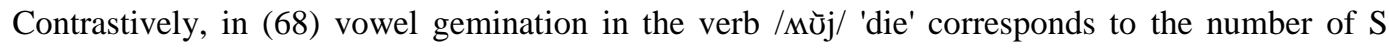
arguments (PARTICIPANT NUMBER). Consider also (69), where the both singular and plural A arguments can be matched with either the singular or plural verb stem of the verb /pàc'í/ 'pound', yielding different semantic effects (rather than ungrammaticality, which would be expected of a concord system). When the number of the A arguments corresponds with that of the derived stem — singular A with singular verb stem (69)a), or plural A with plural verb stem (69)b) - the effect is on the PARTICIPANT NUMBER of the A argument. When the number is mismatched, however, it affects the PARTICIPANT NUMBER of the $\mathrm{O}$ and EVENT NUMBER. A singular A with the plural stem 
yields a variety of $\mathrm{O}$ arguments or perhaps distributive aspect (69)c), and a plural A with the singular stem yields a singular $\mathrm{O}$ or a unary event (69)d).

(69) Vowel gemination affecting PARTICIPANT NUMBER of A and O / EVENT NUMBER
a. $\bar{a} r=$ pàc'í làdà
3SG.M.NOM=pound.SG anvil
'He struck anvil(s).'
b. $\bar{u} n=$ pàāc'í làdà
3PL.NOM=pound.PL anvil
'They struck anvil(s).'
c. $\bar{a} r=$ pàāc'í làdà
3SG.M.NOM=pound.PL anvil
'He struck various anvils.'
d. $\bar{u} n=$ pàc'í làdà
3PL.NOM=pound.sG anvil
'They struck an anvil (in unison).'

3.2.3 Reduplication. Another common strategy for deriving a plural stem is through partial reduplication. This strategy is only attested on monosyllabic roots and takes the form of the onset and nucleus of the root being reduplicated and prefixed to it. Examples Error! Reference source not found. and Error! Reference source not found. illustrate this. Note that in the process of reduplication there is usually tonal modification and that the initial consonant of the root may take a voicing feature (with voiceless unaspirated consonants becoming voiced and implosive consonants become voiced non-implosives).

(70) Reduplication affecting PARTICIPANT NUMBER of $S$
a. ān= bứt
3NH.NOM=be.weak
b. $\bar{a} n=6 \bar{u} \sim b u ́ t ~$
'It is weak.'
$3 \mathrm{NH} . \mathrm{NOM}=$ REDUP $\sim$ be.weak
'They (non-human) are weak'

(71) Reduplication affecting PARTICIPANT NUMBER of O

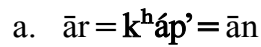
3sG.M.NOM=repair $=3$ NH.ACC

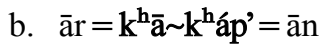
3 SG.M.NOM=REDUP $\sim$ repair $=3$ NH. ACC
'He repaired it.'
'He repaired many/various things.'

Once again the semantics of this root modification depend largely on the lexeme and context. Above are examples of reduplication encoding multiple $S$ participants of a verbal adjective (70), or the variety of $\mathrm{O}$ arguments of a transitive verb (71). Reduplication can also affect EVENT NUMBER of both transitive and intransitive verbs. In (72) with the verb /pi// 'throw', reduplication can encode iterative aspect, in this case a single spear being thrown again and again. In (73) with the verb /kāl/ 'turn aside', it has a similar effect, in this case serial instances of leaving the path.

(72) Reduplication affecting EVENT NUMBER of a transitive verb.
a. $\bar{a} \mathbf{r}=\mathbf{p} \overline{\mathbf{r}}$
nàk $^{\mathrm{h}} \overline{\mathrm{a}}$
3SG.M.NOM=throw spear
b. $\bar{a} r=$ pì $\sim$ bí
nàk ${ }^{\mathrm{h}} \overline{\mathrm{a}}$
3SG.M.NOM=REDUP throw spear
'He threw a spear.'
'He threw a spear repeatedly.' 
(73) Reduplication affecting EVENT NUMBER of an intransitive verb.

a. $\bar{a} r=k a ́ l$

3SG.M.NOM=turn.aside

'He turned aside.' b. $\bar{a} \mathbf{r}=\mathbf{k} \bar{a} \sim k \bar{a} \mathbf{l}$

3SG.M.NOM=REDUP turn.aside

'He turned aside repeatedly / strayed.'

The only semantic gap in the reduplicative strategy is that of an unambiguous effect on

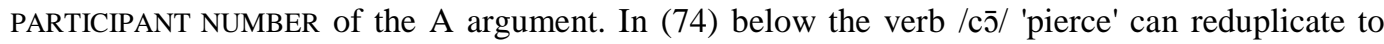
indicate a plural $\mathrm{A}$ in the context of a thorn piercing someone. The A argument in this scene is not prototypically agentive, however, and the same construction could also be used to indicate, for example, a single spear piercing an individual multiple times as in (75).

Reduplication affecting PARTICIPANT NUMBER of A

a. k kák’ā cōn=āgā

thorn pierce $=1 \mathrm{SG} . \mathrm{ACC}$

'A thorn pierced me.' b. k ák'ā có $\sim \mathfrak{j o ́}=\bar{a} g a ̄$

thorn $\quad$ REDUP $\sim$ pierce $=1$ SG.ACC

'Thorns pierced me.'

(75) Reduplication affecting EVENT NUMBER

$\begin{array}{lll}\text { a. } & \text { nàk }{ }^{\mathrm{h}} \overline{\mathrm{a}} & \mathbf{c} \overline{\mathbf{D}}=\overline{\mathrm{a}} \mathrm{r} \\ \text { spear } & \text { pierce }=3 \text { SG.M.ACC }\end{array}$

'A spear pierced him.' b. nàk ${ }^{\mathrm{h}} \overline{\mathrm{a}}$ có $\sim \mathfrak{\jmath}=\overline{\mathrm{a}} \mathrm{r}$

spear $\quad$ REDUP $\sim$ pierce $=3$ SG.M.ACC

'A spear / spears pierced him repeatedly.'

As with the other two morpho-phonemic strategies, semantic effects on PARTICIPANT NUMBER of the $\mathrm{O}$ argument and EVENT NUMBER can become blurred. In such cases it is the scene that is semantically affected by the use of the plural stem, the number of arguments involved being consequent. For example, consider the verbs $/ \mathrm{t}^{\mathrm{h}} \mathrm{u} /$ ' give birth' Error! Reference source not found. and /sū/ 'buy' Error! Reference source not found.. ${ }^{21}$ In Error! Reference source not found.c) and Error! Reference source not found.c) these appear to affect the PARTICIPANT NUMBER of the O argument. Error! Reference source not found.d) and Error! Reference source not found.d) show that attempting these forms with a singular object is ungrammatical. However, comparing these with Error! Reference source not found.a-b) and Error! Reference source not found.a-b) reveals that the unreduplicated form can also take a plural object. The difference between the unreduplicated (b) and reduplicated (c) forms is rather that there are multiple kinds or instances of birthing and buying going on respectively. The number of events being affected (EVENT NUMBER) consequently requires the number of arguments to be affected (PARTICIPANT NUMBER), since it is unnatural to speak of birthing a single child multiple times or buying the same exact cow multiple times.

\footnotetext{
${ }^{21}$ Example Error! Reference source not found. attests some phonologically interesting reduplication. From other examples it is known that a voiceless unaspirated initial consonant on a root will voice after reduplication. Thus, phonetically we would expect /sū/ 'buy' to reduplicate as [sú-zú]. This, however, is a phonemic voicing process, and because Bilugu has merged the phoneme $/ \mathrm{z} /$ with $/ \mathrm{J} /$, the voiced counterpart of /s/ also becomes /J /, and the reduplicated form of/sū/ is /sú-fú/. Compare with Pame/sú-sú/ 'REDUP buy'.
} 
(76)
a. $\bar{a} b=t^{\mathrm{h}} \mathfrak{u}$
àdím $\bar{\varepsilon}$
3SG.F.NOM=give.birth
child

'She bore a child'

b. $\bar{a} b=t^{\mathrm{h}} \mathfrak{u}$

bìt'́

3SG.F.NOM=give.birth children

'She bore children (one father, in one place)'

c. $\bar{a} b=t^{\mathrm{h}} \overline{\mathbf{u}} \sim \mathrm{t}^{\mathrm{h}} \mathbf{u}$

bìt'́

3SG.F.NOM=REDUP give.birth children

'She bore children (various fathers or places)'

d. $* \overline{\mathrm{a}} \mathrm{b}=\mathrm{t}^{\mathrm{h}} \overline{\mathbf{u}} \sim \mathrm{t}^{\mathrm{h}} \mathbf{\mathrm { u }} \quad$ àdím $\bar{\varepsilon}$

*3SG.F.NOM=REDUP give.birth child

*'She bore a child (from a different father?)'

$\begin{array}{llllllll}\text { (77) } & \text { a. } \begin{array}{l}\text { àr=fà } \\ \text { 3SG.M.NOM=go.SG }\end{array} & \text { bì } & \text { gàbàjá, } & \text { fà } & \text { sū } & \text { pì } & \text { djān } \\ \text { market } & \text { go.SG } & \text { buy } & \text { cow } & \text { one }\end{array}$

3SG.M.NOM=go.SG OBL market go.SG buy cow one

'He went to the market and bought one cow.'

b. ār=fà bì gàbàjá, fà sō pìb

3SG.M.NOM=go.SG OBL market, go.SG buy cows

'He went to the market and bought cows.'

c. ār=fà bì gàbàjá, fà sư fú pìb

3SG.M.NOM=go.SG OBL market, go.SG REDUP buy cows

'He went to the market and bought cows (several times or from several vendors).'

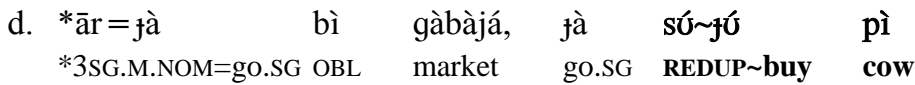

*'He went to the market and (several times) bought a cow.'

3.2.4 Multiple Strategies \& Summary. Finally, a few lexical items attest more than one morpho-phonemically derived plural stem. For example, the verb /gìl/ 'see (vt.)' in (78) may derive a plural stem via vowel gemination (78)b) or reduplication (78)c). The former yields a kind of iterative aspect to a single event (to the effect of 'looking around'), whereas the latter yields a multiplicity of events and $\mathrm{O}$ arguments (multiple instances of seeing a variety of objects).
a. $\quad$ ār $=$ gìl
¡ćkún̄̄
3SG.M.NOM=see
country:MED

'He saw that country.' 
b. $\bar{a} r=g i ̄ i l ~ f c ́ k u ́ n \bar{~}$

3SG.M.NOM=see.PL country:MED

'He looked around at that country.'

c. $\bar{a} r=$ gì gìl fékún

3SG.M.NOM=REDUP $\sim$ See country:MED

'He saw those various countries (at different times / locations).'

From the data presented here in $\$ 3.2$ it is clear that the morpho-phonemic verbal plurals have rather unpredictable semantic effects on both PARTICIPANT NUMBER and EVENT NUMBER (the nuances being lexically and contextually determined). They are a derivational phenomenon, affecting the semantics of the verb rather than agreeing with the grammatical number of the verb's arguments.

\subsection{Lexical Verbal Plurals}

A small group of high-frequency verbs in Bilugu Opo encode VERBAL NUMBER through lexical strategies, either suppletion or stem alternation. Unlike the morpho-phonemic verbal plurals, these forms predictably encode PARTICIPANT NUMBER.

3.3.1 Suppletion. Nine verbs in my lexical database attest a suppletive relationship with another verb root to predictably encode PARTICIPANT NUMBER of the $S$ argument of intransitive verbs, or the $\mathrm{O}$ argument of transitive verbs. In Error! Reference source not found. below I give all nine non-complex pairings (i.e. verb roots, excluding all phrasal or other derived forms). Though few in terms of number of tokens in the lexicon, this set includes some of the more frequent tokens in discourse, some even serving as tense/aspect auxiliaries verbs.

(79) Non-complex suppletive singular plural verb pairings.

$$
\begin{aligned}
& \text { fà } \sim \text { ?já } \quad \text { 'go } \mathrm{SG} \sim \mathrm{PL} \\
& \text { fū f fàā } \quad \text { 'come } S G \sim \text { PL' } \\
& \text { wà k'ó 'dwell, stay } \mathrm{SG} \sim \text { PL' } \\
& \text { tò } \sim \text { 1" 'be present } \mathrm{SG} \sim \mathrm{PL}^{\prime} \\
& \text { tón } \sim \text { cègè } \quad \text { 'be big SG } \sim \text { PL' } \\
& \text { bà } \sim \text { cù } \quad \text { 'lay (intr.) SG } \sim \text { PL' } \\
& \text { wijāa } \sim \text { só 'run } \mathrm{SG} \sim \mathrm{PL}^{\prime} \quad \text { (used for most fluid horizontal motion) } \\
& \text { Sīnā } \sim \mathrm{k}^{\mathrm{h}} \bar{\varepsilon} \mathrm{ja} \overline{\mathrm{a}} \quad \text { 'fall into } \mathrm{SG} \sim \mathrm{PL} \text { ' } \\
& \mathrm{p}^{\mathrm{h}} \overline{\mathrm{a}} \sim \mathrm{d} \overline{\mathrm{o}} \quad \text { 'bring SG } \sim \text { PL' }
\end{aligned}
$$

Semantically these verbs are quite varied: /łà 2já/ 'go', /łū fàā/ 'come', /wījā só/ 'run', /sīnā $\sim \mathrm{k}^{\mathrm{h}} \bar{\varepsilon} \mathrm{j} \bar{a} /$ 'fall into', and $/ \mathrm{p}^{\mathrm{h}} \overline{\mathrm{a}} \sim \mathrm{d} \bar{\jmath} /$ 'bring' indicate translational motion, /bà $~$ cù/ 'lay (intr.)' and /wà $\sim$ k'ó/ 'dwell' indicate static (non-motion) events, and /tò 1̂// 'be present' and /tón cègè/ 'be big' indicate abstract states. It is clear then that besides frequency there is no unifying factor as to which verbs take a suppletive partner. 
Examples (80) and (81) show that the basic semantics being modified between the suppletive pairs in intrasitive verbs is the number of $\mathrm{S}$ participants and not the number of events (a-b). Also, unlike verbs in the previous section, when VERBAL NUMBER of the verb stem and the NOMINAL NUMBER of the $\mathrm{S}$ argument are mismatched the result is ungrammatical (c-d). ${ }^{22}$

(80) Suppletion affecting PARTICIPANT NUMBER of S
a. $\bar{a} \mathbf{r}=\mathfrak{f} \overline{\mathbf{U}}$
3SG.M.NOM=come.SG
b. $\bar{u} n=$ łàa
3PL.NOM=come.PL
'He came.'
'They came (not in multiple events).'
c. $* \bar{a} r=$ łàā
*3SG.M.NOM=come.PL
*'He came (many times?).'
d. $* \bar{u} n=\mathfrak{f} \overline{\mathbf{u}}$
*3PL.NOM=come.SG
*'They came (in a single event?).'

(81) Suppletion affecting PARTICIPANT NUMBER of S
k’áj
3SG.M.NOM=dwell.sG be.good
a. $\bar{a} r=$ wà

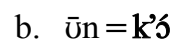
k’áj
3PL.NOM=dwell.PL be.good
'He is well.' (lit. dwell good)
'They are well.' (lit. dwell good)
c. *ār $=\mathbf{k}$ 'ó
$* 3$ SG.M.NOM=dwell.PL
*'He dwells (multiple events?).'
d. *ūn = wà
*3PL.NOM=dwell.sG
*'They dwell (single event?).'

The examples below illustrate the suppletive pairs /bà tfù/ 'lay.SG PL' (82) and /wìjā só/ 'run.SG PL' (83), also affecting the PARTICIPANT NUMBER of the $S$ argument. In both cases, the number value of $\mathrm{S}$ is ambiguous apart from the verb stem.

(82) Suppletion affecting PARTICIPANT NUMBER of S

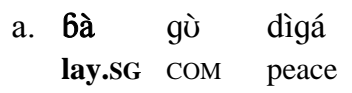
$\begin{array}{lll}\text { b. cù gù dìgá! } & \\ \text { lay.PL } & \text { COM peace }\end{array}$
'(You SG) sleep well!'
'(You PL) sleep well!"

(83) Suppletion affecting PARTICIPANT NUMBER of S
wījā gàmbélà
vehicle $=$ MED run.SG Gambella
a. tòròbíl = ínī
b. tòròbíl =ínī só gàmbélà
vehicle $=$ MED run.PL Gambella
'That vehicle went to Gambella.'
'Those vehicles went to Gambella.'

In certain cases, however, the plural stem of the intransitive verbs is utilized even though the grammatical subject is singular, because the semantics of the situation indicate plural agents. Thus in (84) the plural verb /cù/ 'lay.PL' is used because the act of copulation denotes a plural agent.

\footnotetext{
${ }^{22}$ Otero shows how a similar mismatch gives rise to dual/paucal number in Ethiopian Komo (2015). This is not attested in Bilugu Opo, however.
} 
Grammatically, however, the subject is singular /ùténī/ '3M.SG:MED' and the second participant is placed in a commitative clause.

$$
\begin{aligned}
& \text { ùténī cù gū màs } \\
& \text { 3SG.M:MED lay.PL COM wife.3POSS } \\
& \text { 'That man slept with his wife.' }
\end{aligned}
$$

My lexical database only attests one transitive verb pairing in this group, $/ \mathrm{p}^{\mathrm{h}} \overline{\mathrm{a}} \sim \mathrm{d} \bar{\jmath} /$ 'take', and here the plural stem affects the PARTICIPANT NUMBER of $O$ as seen in (85).

\section{Suppletion affecting PARTICIPANT NUMBER of O}
a. $\bar{a} r=p^{\mathbf{h}} \overline{\mathbf{a}}=\bar{a} n$
3SG.M.NOM=bring.SG $=3$ NH.ACC
b. $\bar{u} n=d \bar{s}=\bar{a} n$
3PL.NOM=bring. $\mathrm{PL}=3 \mathrm{NH} . \mathrm{ACC}$
'He brought it (one thing).'
'They brought it (many things).'
c. $\bar{a} \mathrm{r}=\mathrm{d} \overline{\mathbf{b}}=\overline{\mathrm{a}} \mathrm{n}$
3SG.M.NOM=bring.PL $=3 \mathrm{NH} . \mathrm{ACC}$
d. $\quad \bar{u} n=p^{\mathbf{h}} \overline{\mathbf{a}}=$ àn
3PL.NOM=bring.SG $=3 \mathrm{NH} . \mathrm{ACC}$
'He brought it (many things).'
'They brought it (one thing).'

Similarly, when the intransitive verbs are derived as transitive actions the semantic effect of the plural stem shifts to affect the PARTICIPANT NUMBER of the O argument, thus attesting a kind of absolutive patterning. So in (86) the pair /6à cù/ 'lay.SG PL' can be derived as transitive verbs, becoming /6á cùwà/ 'put.SG PL.' ${ }^{23}$ The plural stem now marks a plurality of $\mathrm{O}$ arguments and can be mixed with the number of the A argument to produce a matrix of meaning: a singular subject with a singular object (86)a), plural subjects with plural objects (86)b), a singular subject with plural objects (86)c), or plural subjects with a singular object (86)d).

(86) Suppletion affecting PARTICIPANT NUMBER of O
a. $\bar{a} r=6 a ̂ a n=\bar{n}$
à-tín $\bar{\varepsilon}$
3SG.M.NOM=put.SG=3NH.ACC SOURCE-down
b. $\bar{u} n=$ cùwà $=\bar{a} n$
à-tín $\bar{\varepsilon}$
3PL.NOM=put.PL=3NH.ACC SOURCE-down
'He put it (one thing) down.'
'They put it (many things) down.'
c. $\bar{a} r=$ cùwà $=\bar{a} n$
à-tín $\bar{\varepsilon}$
3SG.M.NOM=put.PL=3NH.ACC SOURCE-down
'He put it (many things) down.'

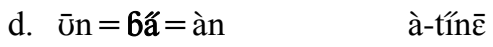
3PL.NOM=put.SG=3NH.ACC SOURCE-down
'They put it (on thing) down.'

\footnotetext{
${ }^{23}$ I have not yet analyzed the means of derivation here, and it is possible these are lexicalized forms, not productive derivations.
} 
Likewise, the verbs /sīnā $\sim \mathrm{k}^{\mathrm{h}} \bar{\varepsilon} \mathrm{j} \overline{\mathrm{a}} /$ 'fall into $\mathrm{SG} \sim$ PL' can be derived as transitive verbs using the deictic directional marker /-(c)há/, becoming /sīnhá $\sim \mathrm{k}^{\mathrm{h}} \overline{\mathrm{\varepsilon}} \mathrm{c}^{\mathrm{h}} \mathrm{a} /$ 'throw SG $\sim \mathrm{PL}$ ' as in (87). ${ }^{24}$ The plural stem now affects the participant number of $\mathrm{O}$ and can be mismatched with the number of $\mathrm{A}$ arguments to change the scene.

(87) Suppletion affecting PARTICIPANT NUMBER of O
a. $\bar{a} \mathbf{r}=\operatorname{sīn}-\mathrm{há}=\overline{\mathrm{a}} \mathrm{n}$
3SG.M.NOM=throw.SG-DD2 $=3 \mathrm{NH} . \mathrm{ACC}$
b. $\bar{u} n=\mathbf{k}^{\mathbf{h}} \bar{\varepsilon}-c^{\mathbf{h}} \mathfrak{a}=\bar{a} n$
3PL.NOM=throw.PL-DD2=3NH.ACC
'He threw it (one thing) away.'
'They threw it (many things) away.'
c. $\bar{a} \mathrm{r}=\mathbf{k}^{\mathrm{h}} \overline{\boldsymbol{\varepsilon}}-\mathrm{c}^{\mathrm{h}} \mathbf{a}=\overline{\mathrm{a}} \mathrm{n}$
3SG.M.NOM=throw.PL-DD2=3NH.ACC
d. $\bar{u} n=\sin n-h a ́=\bar{a} n$
3PL.NOM=throw.SG-DD2 $=3 \mathrm{NH} . \mathrm{ACC}$
'He threw it (many things) away.'
'They threw it (one thing) away.'

3.3.2 Stem Alternation. Bilugu Opo has four verbs which predictably encode PARTICIPANT NUMBER of the nominative argument through stem alternation. By stem alternation, I mean that the singular and plural stems have obviously related but synchronically unpredictable forms. Like the suppletive verbs these are all high-frequency verbs in terms of discourse. In Error! Reference source not found. I show the alternating forms of these four verbs.

(88) Non-complex stem-alternating singular plural verb pairings.
a. $\mathrm{p}^{\mathrm{h}} \mathrm{I} \sim \overline{\mathrm{I}} \mathrm{p}^{\mathrm{h}} \overline{\mathrm{I}} \quad$ 'drink SG $\sim$ PL'
b. sá $\sim \overline{\mathrm{u}} \overline{\mathrm{a}} \quad$ 'eat SG $\sim$ PL' (non-fleshy foods)
c. nāp kànáp 'burn, be angry $\mathrm{SG} \sim$ PL'
d. pùt $\sim$ kàbút 'be satisfied $\mathrm{SG} \sim$ PL'

In (89) and (90) I give examples illustrating the semantic effect on the PARTICIPANT NUMBER of the A arguments for the two transitive verbs, and in (91) I illustrate the effect on the S argument forone of the two intransitive verbs.

(89) Stem alternation affecting PARTICIPANT NUMBER of A
a. sá mà!
eat.SG food
b. ūsā mà!
eat.PL food
'(You SG) eat food!'
'(You PL) eat food!'

(90) Stem alternation affecting PARTICIPANT NUMBER of A
a. phí jì
drink.SG water
b. mí
1PL.INCL.JUSS
$\overline{\mathbf{I}}^{\mathbf{h}} \overline{\mathbf{I}} \quad$ jì
drink.PL water
'(You SG) drink water!'
'Let us (inclusive) drink water!'

\footnotetext{
${ }^{24}$ The deictic directional marker 2 (DD2) for some lexemes is split into two distinct morphemes (see Smolders forthcoming). In this example with this suppletive verb pair, it takes the form /-(c)há/ for the itive or andative sense, but it could also take the form /-á/ to mark second person goal.
} 
(91) Stem alternation affecting PARTICIPANT NUMBER of S
a. ār=nāp àsìmān
3SG.M.NOM=burn.SG very
b. $\overline{\text { nn }}=$ kànáp
3PL.NOM=burn.PL very
'He is very angry'
'They are very angry'

The difference in form between singular and plural stems of these verbs could be analyzed synchronically as irregular plural affixes. However, these were likely formed through historical deletion of the initial syllable of a plural stem originally derived by tonal modification. Evidence for this can be seen in cognates of other Opo dialects and Koman languages, given in Table 14. While this satisfactorily explains the forms of the two transitive verbs, the /*kà/ element of /kànáp/ 'be angry (PL)' and /kàbút/ 'be satisfied (PL)' remains a mystery, since no cognates have any comparable element. ${ }^{25}$

Table 14. Cognates for stem alternating verbal plurals in Opo dialects and Koman languages.

Data for Komo from Otero (2015a, p.c.), for Uduk from Killian (2015. p.c.), and for Gwama from Justin Goldberg (p.c.).

\begin{tabular}{|c|c|c|c|c|c|c|c|c|}
\hline & \multicolumn{4}{|c|}{ Opo } & \multirow{2}{*}{ Komo } & \multirow{2}{*}{ Uduk } & \multirow{2}{*}{ Gwama } \\
\hline & & Bilugu & Modin & Pame & Dana & & & \\
\hline \multirow{2}{*}{ 'eat' } & SG & sá & sá & sá & úfà & Sá & \multirow{2}{*}{ Swá } & \multirow{2}{*}{$\int \bar{a}$} \\
\hline & PL & ūsā & $\bar{u}$ sā & ūsā & ùfá & ù & & \\
\hline \multirow{2}{*}{ 'drink' } & SG & $\mathrm{p}^{\mathrm{h}_{\mathrm{I}}}$ & $\mathrm{p}^{\mathrm{h}} \mathrm{I}_{\mathrm{I}}$ & $\mathrm{I}^{\mathrm{h}}$ & íp $p^{h}$ & íp & \multirow{2}{*}{$\mathrm{p}^{\mathrm{h}} \hat{i}$} & \multirow{2}{*}{ t’ōp' } \\
\hline & PL & $\overline{\mathrm{I}} \mathrm{p}^{\mathrm{h}} \overline{\mathrm{I}}$ & $\overline{\mathrm{I}} \mathrm{p}^{\mathrm{h}} \overline{\mathrm{I}}$ & $\overline{\mathrm{I}} \mathrm{p}^{\mathrm{h}}$ & İph ${ }^{h}$ & ìp & & \\
\hline \multirow{2}{*}{ 'burn' 26} & SG & nāp & nāp & nāp & nāp & \multirow{2}{*}{ năpá } & \multirow{2}{*}{ náp ${ }^{\mathrm{h}} \overline{\mathrm{i}}$} & \multirow{2}{*}{ năpá } \\
\hline & PL & kànáp & kànáp & nàp & nàpí & & & \\
\hline
\end{tabular}

Interestingly, the two transitive verbs /sá/ 'eat' and /phí/ 'drink' also attest a reduplicative plural stem effecting either EVENT NUMBER or PARTICIPANT NUMBER of the O argument. In (92), in the context of drinking traditional sorghum beer, the reduplicated form of $/ \mathrm{p}^{\mathrm{h}} \mathrm{i} /$ yields serial events. In (93), in the context of eating bread-like food, the reduplicated form of /sá/ could either be interpreted as multiple events or as a variety of $\mathrm{O}$ arguments.

(92) Reduplication affecting EVENT NUMBER

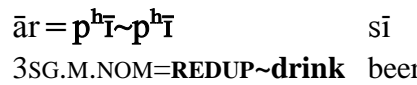

'He drank (traditional) beer (at various times/places).'

\footnotetext{
${ }^{25}$ At present I analyze the verb /kāw kàgáw/ 'be strong SG PL' as partial reduplication, though it could also be analyzed as stem-alternation and thus be another example of the $/ *$ kà-/ prefix.

${ }^{26}$ The cognates for /nāp/ in Komo, Uduk, and Gwama have the meaning 'be disabled'.
} 
(93) Reduplication affecting PARTICIPANT NUMBER of O or EVENT NUMBER

$$
\begin{array}{ll}
\bar{a} \mathrm{r}=\mathrm{s} \overline{\mathrm{a}} \sim \mathrm{s} \overline{\mathrm{a}} & \text { mà } \\
\text { 3sG.M.NOM=REDUP eat } & \text { food }
\end{array}
$$

'He ate various kinds of food / he ate at various times / places.'

Note that these reduplicated forms are based off the singular stem, and do not change depending on the number of A arguments as shown in (94) (i.e. there is no attestation of a reduplication of the alternate plural stem, such as $/ *$ sā $\overline{\mathrm{u}} \mathrm{s} \overline{\mathrm{a}} /$ ).
a. $\bar{u} n=s \bar{a} \sim s \bar{a}$
mà
3SG.M.NOM=REDUP eat food

'They ate various kinds of food / ate at various times / places.'

\subsection{Arguments for Verbal Number}

As noted in $\$ 3.1$, both Corbett (2000) and Newman $(1990,2012)$ define VERBAL NUMBER and PLURACTIONAL respectively in contrast to a system of agreement with NOMINAL NUMBER. The latter is said to be an inflectional verb form predictably triggered by the grammatical number of a particular argument (e.g. the nominative argument). Since I am claiming that the phenomena I have just described in sections $\$ 3.2$ and $\$ 3.3$ are genuine instances of VERBAL NUMBER, in this section I will briefly make my arguments for this and against a system of concord with nominal arguments. My main points are summed up in (95):

(95) Arguments for VERBAL NUMBER and against NOMINAL NUMBER agreement in the Bilugu Opo verb system.

a. Number expression in the verb system is not ubiquitous.

b. Number expression in the verb system is not always obligatory.

c. Number expression in the verb system is semantically and morphologically unpredictable.

d. Number expression in the verb system has all the characteristics of PLURACTIONALITY noted by Newman (2012).

My first point - number expression in the verb system is not ubiquitous (95)a) — refers to the fact that over half of verb roots in my lexical database do not attest a plural stem. Such verbs have a single root form which does not change regardless of extra-verbal changes to the number value of the verb's arguments or events. This can be seen in Error! Reference source not found. with the verb /càní/ 'send'. In Error! Reference source not found.a) I show the base verb form when all arguments and events are semantically singular. In subsequent examples I show that the form /càní/ remains unchanged with a plural subject (96)b), object (96)c), and even events (96)e) (in this case, encoding of multiple events is accomplished by an adverbial phrase). 

a. ār = càyí gáb àdímér
(singular arguments)
3SG.M.NOM=send BEN:3SG.F child:3M.POSS

'He sent her his child'

b. ưn= càní gáb àdím $\bar{\varepsilon}$-mứn

3PL.NOM=send BEN:3SG.F child-3PL.POSS

(plural A)

'They sent her their child'
c. $\bar{a} r=$ càní
gáb
bìt'́r
(plural O)
3SG.M.NOM=send BEN:3SG.F
children:3M.POSS

'He sent her his children'
e. $\bar{a} r=$ càní
gáb àdímér
f⿳亠े $\quad s a ̄ j$
(plural events)
3SG.M.NOM=send
BEN:3SG.F child:3M.POSS
eye be.many

'He sent her his child many times.'

It would be expected that a system of concord with NOMINAL NUMBER, being an inflectional category, would have a much wider application than less than fifty percent of verbs; the majority of verbs should inflect for plural agreement with only a small number of exceptions. Since we find this is not the case in Bilugu Opo, number in the verb system is better analyzed as derivational VERBAL NUMBER.

My second point - number expression in the verb system is not always obligatory (95)b) refers to the attestations of mismatches between the number in the verb stem and that of its arguments (refer to (63), (69), (86), and (87)). Instead of being universally ungrammatical, as would be expected of a system of NOMINAL NUMBER agreement, these mismatches yielded unique semantic effects. This argument even applies for the lexical verbal plurals described in $\$ 3.3$, where mismatched suppletive pairs were attested in constructions that were grammatically singular but semantically plural (refer to (84)), and in cases where these verbs were derived as transitive (refer to (86) and (87)).

My third point - number expression in the verb system is semantically and morphologically unpredictable (95)c) — refers to the fact the same strategy for deriving a plural stem can have very different semantic impact, depending on both lexical and contextual information. This was illustrated abundantly in $\S 3.2$ in relation to the morpho-phonemic strategies, but also holds for the stem-alternating verbal plurals, since they are likely originally tonally distinguished forms and since they also attest reduplicated forms. If verbal number in Bilugu were indeed a system of agreement with NOMINAL NUMBER we would expect predictability between a given strategy and its resulting semantics, and we would certainly not expect effects on EVENT NUMBER.

Point (95)c) also refers to the fact that the same semantic effect is accomplished through diverse morphological strategies. Consider, for example, how the plural stem of verbal colour adjectives are derived using all three morpho-phonemic strategies: tonal modification (97), vowel gemination (98), and reduplication (99). Here we have three different strategies employed to affect PARTICIPANT NUMBER of the $\mathrm{S}$ argument, all within a small set of semantically related verbs. 
(97) Tonal modification affecting PARTICIPANT NUMBER of $S$ in a colour verb
a. $\quad \bar{a} n=$ p’átá
3NH.NOM=be.white.SG
b. $\bar{a} n=$ p'ātá
3NH.NOM=be.white.PL
'It is white.'
'They (non-human) are white.'

(98) Vowel gemination affecting PARTICIPANT NUMBER of $S$ in a colour verb
a. $\bar{a} n=$ cìr
3NH.NOM=be.green.SG
b. $\bar{a} n=$ cìir
$3 \mathrm{NH} . \mathrm{NOM}=$ be.green.PL
'It is green.'
'They (non-human) are green.'

(99) Reduplication affecting PARTICIPANT NUMBER of S in a colour verb
a. $\overline{\mathrm{a}} \mathrm{n}=\mathrm{c}$ 'r
3NH.NOM=be.black.SG

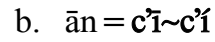
3 NH.NOM=REDUP $\sim$ be.black
'It is black.'
'They (non-human) are black.'

Similarly, with the lexical verbal plurals described in $\S 3.3$, while the semantic effect is more regular than the morpho-phonemic verbal plurals, the form is entirely unpredictable (at least synchronically). Thus, both groups are heavily dependent on lexical information for the form of the plural stem. Contrastively, we would expect a system of agreement with NOMINAL NUMBER to have more predictability of form.

My conclusion is that because number in the verb system is consistently unpredictable, either in form or meaning or both (especially in the morpho-phonemic verbal plurals), these phenomena cannot represent a system of agreement with NOMINAL NUMBER. The lexical verbal plurals could possibly be analyzed as such on the basis of their semantic predictability, but it would be strange to argue for a system of agreement that only applies to thirteen verbs and that has no regular form. Thus, I analyze these as a smaller, irregular set of a larger phenomenon of lexically encoded VERBAL NUMBER.

My final point - number expression in the verb system has all the characteristics of pluractionality noted by Newman (2012) (95)d) - refers to Newman's summary of the key characteristics of PLURACTIONALITY which arose from decades of cross-linguistic publications (2012):

\footnotetext{
What emerged from these studies [... is that] pluractionality involved (a) plurality in the verb per se, (b) derivation rather than inflectional agreement, (c) ergative-type relations with other arguments in the sentence, (d) reduplication as a common means of formation, and (e) the common appearance of suppletive forms. [p.186]
}

Newman's characteristic (a) has been abundantly illustrated for Bilugu Opo by the dependency of form and semantics of VERBAL NUMBER on lexical information. The plural stem does not refer to nor is triggered by grammatical number information external to the verb, but rather is intrinsic to its semantics. Newman's characteristic (b) is closely related this, since he is referring to derivation which affects fundamental semantics, not that which changes word class. In line with this, Newman notes that PLURACTIONAL forms would be expected to serve as the input for further derivation or inflection (2012:192). This is certainly the case in Bilugu Opo with both the morpho-phonemic and 
lexical verbal plurals, which were shown in $§ 2$ to serve as the basis for nominal derivation, and additionally serve as the base of other verbal derivations (e.g. deictic directional derivations, see Smolders forthcoming). Newman's characteristics (c) was seen both in $\$ 3.2 .3$, where reduplicated forms which affected PARTICIPANT NUMBER tended towards absolutive patterning, and in $\S 3.3 .1$ where derived transitive verbs did the same (refer to examples (86)(87)). Finally, Newman's characteristics (d) and (e) are obviously attested, being two of the five strategies for deriving plural stems described above.

\section{Conclusion}

In this paper I have described both NOMINAL NUMBER and VERBAL NUMBER in the Bilugu dialect of Opo. In §2 I showed how NOMINAL NUMBER can be divided into two number systems along the animacy hierarchy: the TOP SYSTEM encompassing all human referents (HR) and encoding a basic singular plural opposition, and the SECOND SYSTEM encompassing all non-human referents (NHR) and encoding GENERAL NUMBER. With regard to the TOP SYSTEM I described three major categories of nominals, each employing different strategies for expressing number: pronouns mark both singular and plural through suppletion (lexically); kinship terms mark plural with the inflectional prefix / $\overline{\mathrm{U}}-/$ 'PL'; the rest of HR nouns fusionally encode number and gender via the third person pronoun bases /*ùtà/ '3SG.M' /*6ā/ '3SG.F' and /*bìjà/ '3PL, their related derivational prefixes /ù-/ '3SG.M', /6ā-/ '3SG.F', and /bì-/ '3PL', or through suppletion (mostly explicable as historical lexicalizations of the derivational morphemes). While most HR nouns mark both singular and plural, ethnonyms and a few other lexemes mark only singular. Regarding the SECOND SYSTEM I showed that while other constituents might be used to specify number, such as quantifiers, attributive nominals, or verbal adjectives, the NHR nominals themselves inherently encode GENERAL NUMBER, which is to say number marking is intrinsically unavailable to them. This is the case regardless of whether an NHR nominal is monomorphemic or morphologically complex, such as derived forms. Finally, I showed how this two-system analysis is confirmed by indexation patterns with the pronominal agreement markers.

In $\$ 3$ I described VERBAL NUMBER (a.k.a PLURACTIONALITY) in Bilugu Opo, differentiating it from NOMINAL NUMBER agreement (which was shown to be marked on the verb via pronominal agreement markers in \$2.4). Following Corbett (2000), I distinguished two types of VERBAL NUMBER based on their semantic effects: PARTICIPANT NUMBER, which affects the multiplicity or variety of a verb's arguments, and EVENT NUMBER, which affects the multiplicity or aspect of events. I then described how verbs expressing such VERBAL NUMBER in Bilugu Opo can be divided into two groups based on the form used for deriving the plural stem and the predictability of the resulting semantics. These are, first, the morpho-phonemic verbal plurals - which derive the plural stem via tone modification, vowel gemination, or reduplication with rather unpredictable semantics - and second, the lexical verbal plurals - which derive the plural stem through suppletion or stem alternation and predictably encode PARTICIPANT NUMBER. In the final section I summarized my arguments for why the phenomena of both the morpho-phonemic verbal plurals and the lexical verbal plurals constitute genuine VERBAL NUMBER as opposed to merely a system of agreement with NOMINAL NUMBER. Specifically, I argued that number in the Opo verb stem is neither ubiquitous nor obligatory, that it is too semantically and morphologically varied to constitute agreement, and further that it bears all the key characteristics of PLURACTIONALITY noted by Newman (2012). 


\section{Abbreviations}

\begin{tabular}{|c|c|c|c|}
\hline 1 & first person & lit. & literally \\
\hline 2 & second person & M & mid tone $(\overline{\mathrm{v}})$ \\
\hline 3 & third person & M & masculine \\
\hline A & subject of transitive verb & MED & medial demonstrative \\
\hline ACC & accusative & $\mathrm{N}$ & noun \\
\hline ASC & associative & $\mathrm{NH}$ & non-human \\
\hline $\mathrm{BE}$ & verb of identity / copula & NEG & negative \\
\hline BEN & benefactive & NHR & non-human referent \\
\hline $\mathrm{COM}$ & commitative & NOM & nominative \\
\hline COMP & complementizer & $\mathrm{O}$ & object of transitive verb \\
\hline CON & connective & OBL & oblique marker \\
\hline DD1 & deictic directional 1 (ventive) & PL & plural / plural verb stem \\
\hline DD2 & deictic directional 2 (itive) & POSS & possessive \\
\hline DIST & distal demonstrative & PROX & proximal demonstrative \\
\hline EXCL & exclusive & REDUP & reduplication \\
\hline $\mathrm{F}$ & feminine & REL & relativizer \\
\hline $\mathrm{H}$ & high tone ('́) & $S$ & subject of intransitive verb \\
\hline HR & human referent & SG & singular / singular verb stem \\
\hline INCL & inclusive & SOURCE & source marker \\
\hline intr. & intransitive & sp. & species \\
\hline IPFV & imperfective & tr. & transitive \\
\hline JUSS & jussive & VOC & vocative \\
\hline $\mathrm{L}$ & low tone (ì) & $X$ & extra-high tone (v") \\
\hline
\end{tabular}

\section{References}

Acquaviva, Paolo. 2003. The Morphosemantics of Transnumeral Nouns. In Proceedings of the Mediterranean Morphology Meetings, 4.251-266.

Bender, M. Lionel (ed.). 1976. The Non-Semitic Languages of Ethiopia (Monograph 5, Committee of Ethiopian Studies, African Studies Center). East Lansing, MI: Michigan State University.

Bender, M. Lionel (ed.). 1983a. Nilo-Saharan Language Studies (Monograph 13, Committee on Northeast African Studies), East Lansing, MI.

Bender, M. Lionel. 1983b. Proto-Koman phonology and lexicon. Afrika und Uebersee 66.259297.

Bender, M. Lionel. 1985. Gumuz, Mao, Koman, Omotic. In Schuh, Russell G. (ed.), Precis from the Fifteenth Conference on African Linguistics. Nilo-Saharan Language Studies (Monograph 13, Committee on Northeast African Studies), East Lansing, MI 1983

Bender, M. Lionel. 1994. Comparative Komuz Grammar. Afrika und Uebersee 77.31-54.

Bender, M. Lionel. 1997. The Nilo-Saharan languages: a comparative essay. 2nd edition. Munich: Lincom Europa.

Bender, M Lionel. 2000. Nilo-Saharan. In Heine, Bernd \& Derek Nurse (eds.), African languages: an introduction, 43-73. Cambridge, UK: Cambridge University Press.

Bender, M. Lionel. 2007. Opuuo. In Siegbert Uhlig (ed.), Encyclopaedia Aethiopica, Vol. 3, 3334. Wiesbaden: Harrassowitz Verlag.

Bender, M. Lionel. 2008. Koman. In Siegbert Uhlig (ed.), Encyclopaedia Aethiopica, Vol. 4, 416418. Wiesbaden: Otto Harrassowitz. 
Bender, M. Lionel. 2010. Opuuo language. In Siegbert Uhlig (ed.), Encyclopaedia Aethiopica, 4.33-34. Wiesbaden: Harrassowitz Verlag.

Burns, Samuel J. 1947. Notes Toward a Grammar of the Koma Language. London: SIM, MS.

Casali, Roderic F. 2008. ATR harmony in African languages. Language and Linguistics Compass 2:496-549.

Casali, Roderic F. 2016. Some Inventory Related Asymmetries in the Pat-terning of Tongue Root Harmony Systems. Studies in African Linguistics 45(1\&2):95-140.

Corbett, Greville G. 2000. Number. Cambridge, UK: Cambridge University Press.

Corfield, F. D. 1938. The Koma. Sudan Notes and Records XXI. 123-165.

Corfield, F. D. 1940. Vocabularies of Shilluk Dialects. SOAS: Ms 39613. 34pp.

Dimmendaal, Gerrit J. 2000. Number Marking and Noun Categorization in Nilo-Saharan Languages. Anthropological Linguistics 42(2).214-26.

Dimmendaal, Gerrit J. 2008. Language ecology and linguistic diversity on the African continent. Language and Linguistics Compass 2(5). 840-858.

Dimmendaal, Gerrit J. 2011. Historical linguistics and the comparative study of African languages. Amsterdam: John Benjamins.

Dimmendaal, Gerrit J. 2014. Nilo-Saharan. In Rochelle Leiber, \& Pavol Štekaur (eds.), The Oxford handbook of derivational morphology, 591-608. Oxford: Oxford University Press.

Dimmendaal, Gerrit J. to appear a. Nilo-Saharan: General overview. In Bedilu Wakijira et al. (eds.), The Oxford handbook of Ethiopian languages, London: Oxford University Press.

Dimmendaal, Gerrit J. to appear b. Areal contact in Nilo-Saharan. In Raymond Hickey (ed.), The Cambridge handbook of areal linguistics, Cambridge: Cambridge University Press.

Ehret, Christopher. 2001. A historical-comparative reconstruction of Nilo-Saharan. Köln: Rüdiger Köppe Verlag.

Greenberg, Joseph H. 1963. The Languages of Africa. Bloomington: Indiana University.

Hammarström, Harald, Robert Forkel, \& Martin Haspelmath. 2017. Glottolog 3.0.

Haspelmath, Martin. 2017. Some principles for language names. Language Documentation \& Conservation 11. 81-93.

Hellenthal, Anne-Christie. 2017. Reduplication in Gwama. Presentation at the 13th Nilo-Saharan Linguistics Colloquium, Addis Ababa, May 3-5, 2017.

Hellenthal, Anne-Christie \& Constance Kutsch Lojenga. 2011. Phonology / Orthography statement for the Gwama language Ttwa Gwama spoken in the Benishangul-Gumuz region, Ethiopia. SIL Ethiopia. Unpublished ms.

Killian, Don. 2015. Topics in Uduk Phonology and Morphosyntax. Helsinki: University of Helsinki.

Killian, Don. 2018. Gender in Uduk. In Francesca Di Garbo \& Bernhard Wälchli (eds.), Grammatical Gender and Linguistic Complexity, 137-160. Berlin: Language Science Press.

Lemi Kebebw. 2010. A Grammatical Description of Opo. MA Thesis, Addis Ababa University.

Mellese Gelaneh. 2017. Documentation and Grammatical Description of Tapo. Addis Ababa, Addis Ababa University PhD Dissertation.

Moravcsik, Edith A. 2017. Number. In Aikhenvald, Alexandra Y. and R. M. W. Dixon (eds.), The Cambridge Handbook of Linguistic Typology, 405-39. Cambridge Handbooks in Language and Linguistics. Cambridge: Cambridge University Press. doi:10.1017/9781316135716.014.

Newman, Paul. 1990. Nominal and verbal plurality in Chadic. Dordrecht: Foris

Newman, Paul. 2012. Pluractional verbs: An overview. In Patricia Cabredo Hofherr and Brenda Laca (eds.), Verbal Plurality and Distributivity, 185-209. Berlin: de Gruyter.

Otero, Manuel A. 2015a. Dual Number in Ethiopian Komo. In Mietzner \& Storch (eds.), NiloSaharan: Models and Descriptions, pp. 123-134, Cologne: Koeppe.

Otero, Manuel A. 2015b. Nominal morphology and 'topic' in Ethiopian Komo. In Osamu Hieda (ed.), Information Structure and Nilotic Languages, 19-35. Tokyo, Japan: Research Institute for Languages and Cultures of Asia and Africa. 
Otero, Manuel A. 2016. Reconstructing pronominal morphology in Koman languages. Paper presented at the 47th Annual Conference on African Linguistics, Berkeley, CA.

Otero, Manuel A. forthcoming. A historical-comparative reconstruction of the Koman languages of the Ethiopia-Sudan borderlands. Eugene, University of Oregon Ph.D. dissertation.

Olejarczuk, Paul, Manuel A. Otero, \& Melissa M. Baese-Berk. 2016. Production and perception of the [ATR] vowel system in Ethiopian Komo. Poster presented at the $171^{\text {st }}$ Meeting of the Acoustical Society of America, Salt Lake City, UT.

Olejarczuk, Paul, Manuel A. Otero, \& Melissa M. Baese-Berk. 2019. Acoustic correlates of anticipatory and progressive [ATR] harmony processes in Ethiopian Komo. Journal of Phonetics 74:18-41.

Payne, Thomas E. 1997. Describing Morphosyntax: a guide for field linguists. Cambridge: Cambridge University Press.

Simons, Gary F. and Charles D. Fennig (eds.). 2017. Ethnologue: Languages of the World, Twentieth edition. Dallas, Texas: SIL International. Online version: http://www.ethnologue.com.

Smolders, Joshua A. G. forthcoming. Aspects of spatial grams in Opo. In Anbessa Teferra, Azeb Amhar \& Binyam S. Mendisu (eds.), Spatial Expressions in Ethiopian Languages.

Snider, Keith. 1999. The Geometry and Features of Tone. Arlington: University of Texas at Arlington \& the Summer Institute of Linguistics.

Snider, Keith. 2017. Tone Analysis for Field Linguists. Dallas: SIL International Publications.

Stevenson, Roland C. 1942. Notes toward a grammar of the Uduk language. MS.

Stump, Gregory T. 1998. Inflection. In Spencer, Andrew \& Arnold M. Zwicky (eds.) The Handbook of Morphology, 13-43. Malden, Oxford, Carlton: Blackwell Publishing.

Van Silfhout, Marijke. 2013a.Opuo: Towards a Phonology. BA Thesis, Leiden University. Van Silfhout, Marijke. 2013b. Opuo: Dictionary. Unpublished paper, Leiden University.

Zelealem Leyew. 2004. The cardinal numerals of Nilo-Saharan languages. In Akinlabí, Akinbiyi M. and Oluseye Adesola (eds.), Proceedings of the 4th world congress of African linguistics, New Brunswick 2003. Köln: Rüdiger Köppe Verlag.

Joshua A. G. Smolders

SIL International

josh_smolders@sil.org 